\title{
Elevated uranium concentrations in Lake Baikal sediments: burial and early diagenesis
}

Lawrence M. Och ${ }^{1}$, Beat Müller ${ }^{1 *}$, Christian März², Adrian Wichser ${ }^{3}$, Elena G. Vologina ${ }^{4}$, Michael Sturm $^{5}$

${ }^{1}$ Eawag, Swiss Federal Institute of Aquatic Science and Technology, CH-6047 Kastanienbaum, Switzerland

${ }^{2}$ Newcastle University, School of Civil Engineering and Geoscience, Newcastle upon Tyne, NE1 7RU, United Kingdom.

${ }^{3}$ Empa, Materials Science and Technology, $\mathrm{CH}-8600$ Dübendorf, Switzerland

${ }^{4}$ Institute of the Earth's Crust, Siberian Branch of the RAS, 128 ul. Lermontova, Irkutsk, 664033, Russia

${ }^{5}$ Eawag, Swiss Federal Institute of Aquatic Science and Technology, Überlandstrasse $133, \mathrm{CH}-8600$ Dübendorf, Switzerland

*Corresponding Author: Beat Müller (ㄹeat.mueller@eawag.ch) phone ++41 587652149 


\section{Abstract}

The water column of Lake Baikal (Siberia) is pervasively oxic and $\mathrm{O}_{2}$ penetrates several $\mathrm{cm}$ into the sediment, followed by distinct layers of Fe/Mn oxide that undergo reductive-dissolution/oxidativeprecipitation cycles. Uranium $(U)$ contents of the oxic surface sediment layers were $\sim 15 \mu \mathrm{g} \mathrm{g}^{-1}$, which is unparalleled in oxygenated lakes. To understand the processes leading to this enrichment we investigated the geochemical composition of the particulate matter and pore water of four sediment cores from different locations in the lake and performed mass balance calculations based on sediment mass accumulation rates and published loads from major tributaries. The comparison of loads and export of $U$ in Lake Baikal suggested that current estimates of loads are too low by a factor of about 3 compared to sediment mass accumulation rates. Peak loads during spring ice melt in tributaries that are difficult to monitor and quantify might be the main cause for the deviation. The high $U$ concentrations in the lake sediments originated from the scavenging of $U$ in the water column through association with settling organic particles and particulate Fe(III)- and, to a lesser extent, $\mathrm{Mn}(\mathrm{IV})$-oxides. We outline the hypothesis that two distinct $U$ phases, lithogenic and non-lithogenic $U$ reach the lake sediment and that authigenic $U$ is subsequently formed under reducing conditions within the sediment. In some cores we found that most $U$ was remobilized during the degradation of organic matter, in particular within the top oxygenated layer of the sediment. Significant enrichments prevailed due to $\mathrm{U}$ adsorption to and/or co-precipitation with Fe-oxides. When Feoxides and, to a lesser extent, Mn-oxides were reductively dissolved, they released $U$ to the pore water, leading to peak dissolved $U$ concentrations in the anoxic sediment, which in turn, precipitated as authigenic $\mathrm{U}$ under predominantly sulphate-reducing conditions. The onset of the accumulation of authigenic $\mathrm{U}$ coincided with the formation of distinct Fe/Mn oxide layers above. We argue that the resilience of Fe-oxides (especially crystalline goethite and hematite), in association with phosphate, even within reducing (but non-sulfidic) sediments support the burial of substantial amounts of U.

Keywords: Uranium diagenesis; Lake Baikal; trace elements; Fe- and Mn-oxides; biogeochemical cycling in lacustrine surface sediments and pore water 


\section{Introduction}

On Earth's surface environment, uranium (U), a radioactive metal from the actinide series, primarily occurs in two redox states with distinctly different physico-chemical characteristics. Under oxic conditions, such as in modern seawater, $\mathrm{U}$ is predominantly present as soluble and stable $\mathrm{U}(\mathrm{VI})$ carbonate complex $\left(\mathrm{UO}_{2}\left(\mathrm{CO}_{3}\right)_{3}{ }^{4-}\right)$ with a concentration of around $3.3 \mu \mathrm{g} \mathrm{I} \mathrm{I}^{-1}(14 \mathrm{nM})$ and exhibits conservative behaviour with a high oceanic residence time of 0.3 to 0.6 million years (Ku et al., 1977; Dunk et al., 2002). U concentrations in freshwater lakes are usually about one or two orders of magnitude lower than in the ocean (e.g. Falkner et al., 1997; Nagao et al., 2002; Chappaz et al., 2010; Li et al., 2011), depending on the lithology of the lake's watershed (Palmer and Edmond, 1993; Windom et al., 2000; Dunk et al., 2002; Andersen et al., 2016). The largest single sink for $U$ in the ocean is by diffusion across the sediment-water interface into organic-rich, oxygen-depleted sediments (Anderson et al., 1989; Klinkhammer and Palmer, 1991; Calvert and Pedersen, 1993; Morford and Emerson, 1999). Here it can be reduced to U(IV) at sedimentary redox conditions near those for the conversion of $\mathrm{Fe}(\mathrm{III})$ to $\mathrm{Fe}(\mathrm{II})$ (Ginder-Vogel et al., 2006), and precipitate either as uraninite $\left(\mathrm{UO}_{2}\right), \mathrm{U}_{3} \mathrm{O}_{7}$ or $\mathrm{U}_{3} \mathrm{O}_{8}$ (e.g. Klinkhammer and Palmer, 1991; Crusius et al., 1996) or as a monomeric U(IV) species that readily associates with phosphate or carbonate functional groups (e.g. Bargar et al., 2013; Morin et al., 2016). Thereby, microbially mediated reduction of aqueous U(VI) to sparingly soluble $\mathrm{U}(\mathrm{IV})$ is considered to be the most important process controlling the biogeochemical cycling of $U$ in the subsurface (Williams et al., 2013; Bargar et al., 2013). In Phanerozoic times, where significantly higher atmospheric and oceanic $\mathrm{O}_{2}$ concentrations allowed for a more pronounced role of oxygen in the $U$ cycle, this may have been responsible for $U$ contents in black shale of well above $100 \mu \mathrm{g} \mathrm{g}^{-1}$ (Partin et al., 2013).. Redox transitions influence the ${ }^{238} \mathrm{U}^{235} \mathrm{U}$ isotope ratio, which makes sedimentary $U$ an important redox tracer due to the distinctly different geochemical behaviour of the reduced and oxidized species, and the long residence time in the ocean (Brennecka et al., 2011; Andersen et al., 2016). A detailed understanding of the processes involved in the accumulation of $U$ in the sediment and during early diagenesis is thus required. 
In addition, uranium is associated with particulate matter in the water column, termed particulate non-lithogenic U (PNU; Anderson, 1982), either in the form of organic complexes (Knauss and Ku, 1983; Hirose and Sugimura, 1991) or co-precipitated with Mn- and Fe-oxides (Duff et al., 2002; Dunk et al., 2002; Cumberland et al., 2016). In well-oxygenated marine and lacustrine sediments, U concentrations typically remain in the range found within the Earth's crust, i.e. around $2.8 \mu \mathrm{g} \mathrm{g}^{-1}$ (Taylor and McLennan, 1995). However, $\mathrm{U}$ concentrations of up to $250 \mu \mathrm{g} \mathrm{g}^{-1}$ may be present in phosphatic rocks, and fine-grained sedimentary rocks typically contain more $\mathrm{U}$ than coarser-grained rocks due to the presence of clays and organic matter to which $U$ adsorbs (e.g. Bird, 2012).

Oligotrophic (nutrient poor) and pervasively oxic Lake Baikal (Siberia, Russia) is the largest lake on Earth by volume and harbours about $20 \%$ of the world's available freshwater resources. Its watershed is dominated by granitoid rocks (Fagel et al., 2007), which, compared to other contemporary lacustrine environments, contribute to a comparatively elevated average $U$ concentration of $420 \mathrm{ng} \mathrm{l}^{-1}$ in the water column (Falkner et al., 1991, 1997). However, despite high $\mathrm{O}_{2}$ concentrations down to the lake bottom and into the top sediment layer, it has been shown that sedimentary $\mathrm{U}$ contents can reach more than $20 \mu \mathrm{g} \mathrm{g}^{-1}$ (Petrov et al., 1999; Zhmodik et al., 2003, 2005; Chebykin et al., 2004, 2007; Goldberg et al., 2005), i.e. about 5 times higher than the rocks of Lake Baikal's watershed (Jahn et al., 2009; Litvinovsky et al., 2011). These U concentrations are also far higher than observed in other freshwater lake sediments where they typically range from 0.5 to 5 $\mu \mathrm{g} \mathrm{g}^{-1}$ (e.g. Markich, 2002). Mass balance calculations result in a $\mathrm{U}$ residence time of about 160 years in the water column, compared to 400 years for Lake Baikal's water mass (Falkner et al., 1997), suggesting that a significant portion of $U$ is removed into, and permanently buried within the sediment. This is striking when considering that the residence time of $U$ in the ocean exceeds the one for its water by about two magnitudes.

In this manuscript, we investigate and discuss the transport and settling of $U$ in the sediment, and processes of remobilization and final sequestration during early sediment diagenesis leading to the high sediment content of $U$. The present study represents the third project on the diagenetic 
evolution and elemental composition of Lake Baikal sediments and pore water based on the same sediment cores (Och et al., 2012; Och et al., 2014).

\section{Environmental setting}

Lake Baikal is situated on an active continental rift that separates the Siberian craton in the northwest from the Mongolian-Transbaikalian belt in the southeast (see Fig. 1; Hutchinson et al., 1992; Moore et al., 1997; Logatchev, 2003). The onset of the rifting dates to the Oligocene (34- 23 Ma; Mats and Perepelova, 2011). While the lake remained free of permanent ice cover throughout the Pleistocene epoch (Kashiwaya et al., 2001), it freezes over for four to five months a year (December to May). Following the ice break up and snow melt around May, a short term increase in terrigenous input is observed (Heim et al., 2005; Zakharova et al., 2005). Most of Lake Baikal's catchment of about $557^{\prime} 000 \mathrm{~km}^{2}$ is sparsely populated and, hence, suffers little anthropogenic contamination. A major $U$ enrichment plant situated by the Angara River, the lake's only outflow, about $40 \mathrm{~km}$ downstream of Irkutsk, was only established in the mid-twentieth century and is unlikely to have a major impact on sedimentary U in Lake Baikal (e.g. Khlopkov, 2008; Moore et al., 2009). However, major $U$ mining operations are located in the eastern transbaikalian region (Ischukova, 1997; Brunello et al., 2006; Laverov et al., 2009). One of the latter is the Khiagda ore field in the Vitim uranium district about $140 \mathrm{~km}$ north of Chita, whereby mineralization occurs within fluvial sediments in paleovalleys of relatively narrow tributaries (e.g. Doynikova et al., 2014). The Vitim U district, however, is located outside the watershed of Lake Baikal (see Fig. S1 in the supplementary information). Nonetheless, we cannot exclude that other $U$ ore deposits, which may have an influence on $U$ delivery to Lake Baikal, occur within the watershed, particularly in the Mongolian part.

The total riverine water input to the lake amounts to about $58 \mathrm{~km}^{3} \mathrm{a}^{-1}$ (Votintsev et al., 1965; Falkner et al., 1997). All the rivers together carry approximately $3780 \mathrm{kt}$ of suspended particulate matter per year (Vologina and Sturm, 2009). The largest river is the Selenga, which contributes $50 \%$ of the water 
and about $75 \%$ of the particle load to the lake. The input of fluvial suspended particles southwards from the Selenga Delta is about twice as high as that to the north (Granina et al., 2000, 2004; Müller et al., 2005). The second and third largest rivers, the Upper Angara and the Barguzin, contribute to $20 \%$ and $7 \%$ of the water, $15 \%$ and $6 \%$ of the particle load, respectively. The Aeolian contributions account for about $6 \%$ of the total particulate matter supply to the lake (Agafonov, 1990; Lomonosov et al., 1995; Granina et al., 2000; Fagel et al., 2007).

In summary, $40 \%$ of the total terrigenous matter delivered to the lake goes to the South Basin, $32 \%$ to the Central Basin and 28\% to the North Basin (Vologina and Sturm, 2009), which constitutes an overall balanced input. However, according to Table 1, about $90 \%$ of total dissolved U introduced into the lake, around 46 tons per year, comes from the Selenga River (Edgington et al., 1996; Falkner et al., 1997), which also delivers around 18 tons $U$ per year contained in particulate matter (calculated using data by Bobrov et al., 2001).

\section{Methods and Materials}

\subsection{Sampling sites and core description}

Sediment cores were collected during an expedition between June 25 and July 2, 2010 at stations A-D from water depths of about $1400 \mathrm{~m}, 490 \mathrm{~m}, 380 \mathrm{~m}$ and $900 \mathrm{~m}$ respectively (Figure 1). Up to nine cores per site were retrieved simultaneously using an uwitec mulitcorer (www.uwitec.at). Unfortunately, the multi-coring device was lost at station D in the North Basin, and cores had to be retrieved individually one by one. Hence, some geochemical profiles from station D can be slightly out of alignment due to the vessel drifting during coring (see also Och et al., 2012).

All cores are mainly composed of biogenic-terrigenous mud whereby diatom remains represent an important component (Figure 2; see also Och et al., 2012). In addition, turbidite deposits have been observed in core A and D. No indications for bioturbation were apparent in either core. The oxidized zone, indicated by different shades of brown including oxidized crusts, can be discontinuous, i.e. 
disrupted by reduced, grey sediments, which is most visible in cores A and C. The depicted core segments of the surface sediment represent deposition of about 200 years for cores A and C, 360 years for core B and roughly 500 years for core $D$.

\subsection{Sample treatment and ICP-MS analysis}

The procedures of sampling and analysis are given in detail in Och et al. (2014). In short, the sediment cores were sectioned in slices of 5 to $15 \mathrm{~mm}$ thickness with an uwitec piston extruder on site, transferred to filter holders of $70 \mathrm{~mm}$ diameter with $0.45 \mu \mathrm{m}$ membrane filters (cellulose acetate, Sartorius 11106-85, Germany) and the porewater extracted with a vacuum flask. Aliquots were acidified with $5 \mu \mathrm{HNO}_{3}$ (conc. suprapure, Sigma Aldrich) for trace element analyses. The remaining sediment was freeze-dried 7 to 10 days after retrieval, ground in an agate mortar and digested with Aqua Regia in a microwave system MLS START (Milestone Inc., USA). Three reference lake sediments from the Canadian Certified Reference Material Project were used for quality control. All digestions were performed in duplicate and results presented as averages. Samples were analysed against ICP element standards (Merck and Alfa Aesar) by inductively coupled plasma mass spectrometry (ICP-MS) using a high resolution magnetic sector field instrument Element 2 (Thermo Scientific, Germany) with Rhodium as an internal standard. The reproducibility varied with the element concentration, i.e. ca. $20 \%$ for contents in the sub ppb range and ca. $5 \%$ for contents above $100 \mathrm{ppb}$.

\subsection{Sequential iron extraction}

Sedimentary Fe speciation was determined using a modified version of the sequential extraction technique by Poulton and Canfield (2005). Around $80-85 \mathrm{mg}$ of freeze-dried, ground samples were subjected to a $0.5 \mathrm{~N} \mathrm{HCl}$ extraction for 1 hour. This released amorphous to weakly crystalline hydrous ferric oxides (e.g. ferrihydrite, lepidocrocite) plus any Fe(II) associated with particle surfaces, Fecarbonates, -phosphates or -monosulphides (Thamdrup et al., 1994; Zegeye et al., 2012; Goldberg et al., 2012). Directly after the extraction, Fe(II) in the extraction solution was determined using ferrozine and a UV/Vis spectrophotometer (Thermo Genesys 6) at a wavelength of $562 \mathrm{~nm}$ (Stookey, 
1970). The remaining extraction solution was analysed for total extracted Fe(II+III) using an atomic adsorption spectrometer (AAS Varian SpectrAA 400), and Fe(III) was calculated as the difference between Fe(II) and total extracted Fe. Crystalline ferric oxyhydroxides (e.g. goethite, hematite) were extracted using a 2 hour sodium dithionite extraction, and magnetite was determined via a 6 hour sodium oxalate extraction, both followed by Fe analysis via AAS.

\subsection{Uranium speciation and flux calculations}

Thermodynamic equilibrium calculations of dissolved $U$ species were performed using the software ChemEQL (Müller, 1996: www.eawag.ch/en/department/surf/projects/chemeql). We applied equilibrium constants compiled by Chappaz et al. (2010) and used concentrations of $\mathrm{Ca}^{2+}, \mathrm{UO}_{2}{ }^{2+}$ and $\mathrm{HCO}_{3}{ }^{-}$typically found in Lake Baikal sediment pore waters (Pogodaeva et al., 2007; Torres et al., 2014). Sorption of $\mathrm{UO}_{2}{ }^{2+}$ and $\mathrm{UO}_{2} \mathrm{CO}_{3}$ to Fe-oxide surfaces was modelled considering two types of sorbing sites, weak and strong with complexation constants selected by Chappaz et al. (2010), and electrostatic interaction was calculated with the Generalized Two Layer Model suggested by Dzombak and Morel (1990). Humic substances, which can play an important role in U speciation in sediment pore waters (e.g. Markich, 2002; Cumberland et al., 2016), were not considered in the present study. Areal pore water fluxes $\left(\mathrm{J}_{\text {sed }}\right)$ were determined from concentration gradients $(\mathrm{dC} / \mathrm{dx})$ applying Fick's first law of diffusion (see also Schulz, 2006):

$J_{\text {Sed }}=\phi * D_{\text {Sed }} * \frac{d C}{d x}$

$D_{\text {Sed }}=\frac{D^{0}}{\phi * F}$

where $D_{\text {sed }}$ is the effective diffusion constant in the sediment, $\phi$ the porosity calculated according to Och et al. (2012), and $F$ the formation factor (Berner, 1980), which is approximated by $F=\phi^{-1.81}$ (Maerki et al., 2004). Molecular diffusion coefficients $\left(D^{0}\right)$ for the dissolved $U$ species dominant in freshwater environments, such as $\mathrm{UO}_{2} \mathrm{CO}_{3}$ and $\mathrm{Ca}_{2} \mathrm{UO}_{2}\left(\mathrm{CO}_{3}\right)_{3}$, can be approximated using the equation from Schwarzenbach et al. (1993): 
$D^{0}=\frac{2.7 \times 10^{-4}}{M^{0.71}}$

where $\mathrm{M}$ represents the molecular mass. As a result, $\mathrm{D}^{0}$ at $25^{\circ} \mathrm{C}$ is $4.4 \times 10^{-6} \mathrm{~cm}^{2} \mathrm{~s}^{-1}$ for $\mathrm{UO}_{2} \mathrm{CO}_{3}$, and $3.1 \times 10^{-6} \mathrm{~cm}^{2} \mathrm{~s}^{-1}$ for $\mathrm{Ca}_{2} \mathrm{UO}_{2}\left(\mathrm{CO}_{3}\right)_{3}$ (see also Zheng et al., 2002b; McManus et al., 2005; Chappaz et al., 2010). After adjusting for $5^{\circ} \mathrm{C}$ with the Stokes-Einstein relation (Li and Gregory, 1974):

$\frac{D_{25^{\circ} \mathrm{C}}^{0}}{D_{5^{\circ} \mathrm{C}}^{0}}=\frac{\eta_{5^{\circ} \mathrm{C}}^{0}}{\eta_{25^{\circ} \mathrm{C}}^{0}} \times \frac{298.15}{278.15}=1.81$

where $\eta$ stands for the temperature-dependent viscosity of water, $D^{0}$ values diminish to $2.4 \times 10^{-6}$ $\mathrm{cm}^{2} \mathrm{~s}^{-1}$ for $\mathrm{UO}_{2} \mathrm{CO}_{3}$, and to $1.7 \times 10^{-6} \mathrm{~cm}^{2} \mathrm{~s}^{-1}$ for $\mathrm{Ca}_{2} \mathrm{UO}_{2}\left(\mathrm{CO}_{3}\right)_{3}$. In the present study, these values will be considered for calculation of maximum and minimum diffusive fluxes, respectively.

\subsection{Lithogenic, non-lithogenic and authigenic uranium}

In modern surface environments it is appropriate to differentiate between three different $U$ pools based on their origin and formation: (1) lithogenic $U$, which represents $U$ bound to minerals of the predominantly granitoid rocks occurring in the catchment of Lake Baikal, i.e. the MongolianTransbaikalian Belt (MTB); (2) non-lithogenic $U$ comprising $U$ scavenged by particulate matter in the water column; and (3) authigenic $U$ precipitated in the sediment due to diagenetic processes. While granites contain about $4 \mu \mathrm{g} \mathrm{g}{ }^{-1} \mathrm{U}$ on average (e.g. Condie, 1993), the granitoid rocks in the MTB have $\mathrm{U}$ contents averaging $3.4 \pm 1.7 \mu \mathrm{g} \mathrm{g}^{-1}(\mathrm{n}=27$; Litvinovsky et al., 2011). However, normalization with the immobile element $\mathrm{Al}$ reveals average $\mathrm{U} / \mathrm{Al}$ ratios of $4.4 \times 10^{-5}(\mathrm{w} / \mathrm{w})$, more than twice the lithogenic average (e.g. Rudnick and Gao, 2004; see also Och et al., 2014) and significantly higher than average granite (ca. $3 \times 10^{-5}$; Condie, 1993). Normalization with the equally conservative element Sc (e.g. De Groot, 1995, Audry et al., 2004) yields U/Sc ratios of about 1 for the MTB granitoid rocks, which is comparable to average granite. Due to the very large watershed of Lake Baikal we assume this ratio to be more or less constant within lithogenic particles settling in Lake Baikal. In addition, contrary to cores $B$ to $D$, the Al concentration profile through core $A$ shows very high variability and is rather different from the Sc profile, leading to spurious correlations between 
various other elements for as yet unknown reasons (see Och et al., 2014). Hence, in order to gain consistency among all studied cores, we calculated the relative abundance of lithogenic $U$ relative to Sc according to the equations:

$U_{L}+U_{N L}=U_{M}$

$U_{L}=S c_{M} \times \frac{U}{S c_{L}}$

The subscript NL denotes the non-lithogenic fraction, the subscript $\mathrm{M}$ stands for measured values and $(\mathrm{U} / \mathrm{SC})_{\llcorner}$is the average lithogenic ratio found in granitoid rocks of the MTB (0.97). The authigenic $U$ fraction, $U_{\text {auth, }}$ which will be more amply discussed later, is part of non-lithogenic $U$ but is explicitly formed within the sediment and will be estimated based on the $U_{\mathrm{NL}}$ and pore water $U$ profiles.

\section{Results}

\subsection{Oxygen in the sediment and particulate $\mathrm{Mn}$ and Fe profiles}

In the present study, the sediment penetration depth of $\mathrm{O}_{2}$ is taken into account (see Fig. 2), which has been measured and discussed for the same cores in Och et al. (2012). Bottom $\mathrm{O}_{2}$ concentrations were between 11.5 and $13.2 \mathrm{mg} \mathrm{l}^{-1}$. The upper Fe/Mn layers or crusts likely form at the lower end of the oxygen penetration depth as a dynamic pattern, moving upwards with the growing sediment. Thereby, reductive dissolution of $\mathrm{Mn}(\mathrm{IV})$ occurs at the lower margin, and upward diffusing $\mathrm{Mn}(\mathrm{II})$ is oxidised with $\mathrm{O}_{2}$. The buried, lower Fe/Mn layers were immobilized within the sediment and undergo slow reductive dissolution mainly driven by the anaerobic oxidation of $\mathrm{CH}_{4}$. Och et al. (2012) suggested a cyclic pattern where the burial of a Fe/Mn layer is accompanied by the generation of a new enrichment at the $02 / \mathrm{Mn}$ (II) redox boundary, which is subsequently nourished by the slowly dissolving old layer. The distribution of $\mathrm{Mn}(\mathrm{IV}), \mathrm{Fe}(\mathrm{III})$, total organic carbon (TOC) and total sulphur (TS) in the sediment cores from the same publication are used in this study for a better 
understanding of the biogeochemical cycling of major and trace metals that potentially affect the distribution of $U$ (see Fig. 2).

\subsection{Uranium speciation}

Thermodynamic equilibrium calculations with ChemEQL considering a pH between 6 and 8 , typical for Lake Baikal sediment pore water (Maerki et al., 2006), suggested that the main U species expected in the pore waters were $\mathrm{UO}_{2} \mathrm{CO}_{3}$ and $\mathrm{Ca}_{2} \mathrm{UO}_{2}\left(\mathrm{CO}_{3}\right)_{3}$, with some $\mathrm{UO}_{2}\left(\mathrm{CO}_{3}\right)_{2}^{2-}$ (see Fig. 3a), i.e. (Ca)- $-\mathrm{OO}_{2}-\mathrm{CO}_{3}$ complexes. The redox potential Eh within Lake Baikal sediments is not explicitly known but can be approximated using concentrations of pore water $\mathrm{Fe}(\mathrm{II})$ using the equation:

$\log \left[\mathrm{Fe}^{2+}\right]=-\frac{1}{0.059} \times E h-1.8$

Thereby, $\mathrm{pE}=16.9 \mathrm{Eh}$ (see Fig. 3). Besides $\mathrm{pH}$ and $\mathrm{Eh}$, pore water $\mathrm{Ca}^{2+}$ and $\mathrm{HCO}_{3}{ }^{-}$concentrations are the relevant parameters. It has been shown that $\mathrm{Ca}^{2+}$ and $\mathrm{HCO}_{3}{ }^{-}$can significantly lower the reduction potential due to the formation of $\mathrm{Ca}-\mathrm{UO}_{2}-\mathrm{CO}_{3}$ complexes and that may hinder bacterial reduction of U(VI) (Phillips et al., 1995; Brooks et al., 2003; Fox et al., 2006; Stewart et al., 2010). In the pore water analysed for the present study, $\mathrm{Ca}^{2+}$ concentrations were mainly in the range of 12 to $25 \mathrm{mg} \mathrm{I}^{-1}$ ( 0.3 to $0.6 \mathrm{mmol} \mathrm{I}^{-1}$; Pogodaeva et al., 2007). $\mathrm{HCO}_{3}^{-}$concentrations were measured (or calculated) in previous studies and ranged between 30 and $100 \mathrm{mg} \mathrm{l}^{-1}$, i.e. 0.5 and $1.6 \mathrm{mmol} \mathrm{I}^{-1}$, within the uppermost $50 \mathrm{~cm}$ of the sediments, and typically increased to more than $100 \mathrm{mg} \mathrm{I}^{-1}$ downcore from the sediment-water interface (Maerki et al., 2006; Pogodaeva et al., 2007). However, when including adsorption reactions between Fe-oxides and $U$ as shown in Figure 3b (Davis, 2001; Chappaz et al., 2010), the formation of $(\mathrm{FeO})_{2}=\mathrm{UO}_{2} \mathrm{CO}_{3}{ }^{2-}$ complexes becomes prevalent at lower $\mathrm{pH}$ and successively replaces $\mathrm{Ca}-\mathrm{UO}_{2}-\mathrm{CO}_{3}$ with increasing sorption sites.

\subsection{Nonlithogenic and authigenic uranium formation}

Figure 4 shows the percentages of the $U_{\mathrm{L}}$ and $U_{\mathrm{NL}}$ fractions, and an estimate for authigenic uranium, $U_{\text {auth}}$, based on the premise that $U_{N L}$ derived from settling particles either remained unreactive or 
decreased with age/depth of the sediment through either reductive dissolution of oxidized host phases or its release through the degradation of organic matter. At the sediment-water interface, $U_{\mathrm{NL}}$ made up for $65 \%$ of $\mathrm{U}_{\mathrm{M}}$ in core $\mathrm{C}$, up to $85 \%$ in core $\mathrm{D}$, and ca. $75 \%$ in cores $\mathrm{A}$ and $\mathrm{B}$. In core $\mathrm{A}$ from the Southern Basin, and core C from the Academician Ridge, the application of equation (6) indicated complete remobilization of $U_{N L}$ at depth. However, as the calculated minima for $U_{N L}$ in core $A$ and $C$ were below zero with -0.15 and $-1.7 \mu \mathrm{g} \mathrm{g} \mathrm{g}^{-1}$, respectively, these estimates have to be considered with some caution. While the former lies well within an analytical error of the Sc and/or U concentrations of less than $2 \%$, the latter either results from an analytical error of up to $20 \%$ or illustrates the incidence of slightly varying $\mathrm{U} / \mathrm{Sc}$ ratios in the inputs to Lake Baikal through time.

\subsection{Core A}

In the sediments of core $A$ (Fig. 2 ), $U_{\mathrm{NL}}$ contents declined rapidly from $16.5 \mu \mathrm{g} \mathrm{g} \mathrm{g}^{-1}$ below the sedimentwater interface and remained relatively constant (between 8.8 and $9.6 \mu \mathrm{g} \mathrm{g}^{-1}$ down to the upper $\mathrm{Fe} / \mathrm{Mn}$ accumulation, followed by a steep decrease down to about $5 \mu \mathrm{g} \mathrm{g}^{-1}$. Between both Fe/Mn enrichments, a single $U_{N L}$ peak of $12 \mu \mathrm{g} \mathrm{g}^{-1}$ was observed at 5 to $6 \mathrm{~cm}$ depth with a concomitant maximum in pore water $\mathrm{U}$ of $9 \mu \mathrm{g} \mathrm{I}^{-1}$. In addition, there were minor peaks of pore water $\mathrm{Fe}(\mathrm{II})$ and $\mathrm{Mn}(\mathrm{II})$ at the same depth, framed by two higher peaks concomitant with the Fe-oxide layers. Below

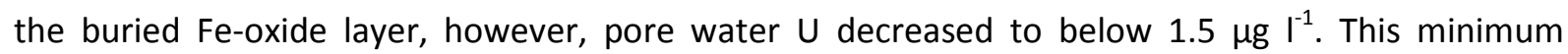
coincided with low pore water Fe(II) concentrations and steeply increasing TS contents decoupled from the TOC profile. At the bottom of the core, pore water $\mathrm{U}$ increased again in concert with $\mathrm{Fe}(\mathrm{II})$ concentrations. $U_{\text {auth }}$ was likely formed where maximum peaks of $U_{N L}$ were observed, i.e. between 5 and $6 \mathrm{~cm}$ and around $11 \mathrm{~cm}$ depth, where it accounted for up to $20 \%$ of total particulate $U$. The $U_{\text {auth }}$ enrichment at ca. $11 \mathrm{~cm}$ depth was further indicated by diffusive fluxes of dissolved $\mathrm{U}$ from above and below the enrichment.

\subsection{Core B}


In core B (Fig. 2), $U_{\mathrm{NL}}$ contents were constant at $\sim 11 \mu \mathrm{g} \mathrm{g}{ }^{-1}$ within the uppermost $12 \mathrm{~cm}$ of the sediment, then decreased to a minimum of $<6 \mu \mathrm{g} \mathrm{g}^{-1}$ within the buried Mn-oxide layer followed by a steep increase to a maximum of $\sim 18 \mu \mathrm{g} \mathrm{g}^{-1}$ right below the Fe-oxide peak at $21 \mathrm{~cm}$. Lower values occurred towards the bottom of the core. The maximum accumulation of $U_{\mathrm{NL}}$ was concomitant with a peak in pore water $\mathrm{Fe}$ and right above a decrease in $\mathrm{SO}_{4}{ }^{2-}$. Pore water $\mathrm{U}$ concentrations were below $2.5 \mu \mathrm{g} \mathrm{l^{-1 }}$ down to the buried Fe-oxide enrichment, and reached peak concentrations of $13.5 \mu \mathrm{g}^{-1}$ at $22.5 \mathrm{~cm}$. The pore water $\mathrm{U}$ peak coincided with the maximum dissolved $\mathrm{Mn}$ concentration of $6 \mathrm{mg} \mathrm{I}^{-1}$. An $U_{\text {auth }}$ enrichment likely occurred below the buried Mn/Fe-oxide layer at $20-25 \mathrm{~cm}$ depth, accounting for up to $20 \%$ of total particulate $U$.

\subsection{Core C}

Core $\mathrm{C}$ exhibited clear boundaries between grey and brown intervals visualizing relative amounts of oxidized Fe (see Fig. 2 and 5), and hence indicated more pronounced redox gradients as compared to most of core B. $U_{\mathrm{NL}}$ contents were $\sim 10 \mu \mathrm{g} \mathrm{g}{ }^{-1}$ down to the upper $\mathrm{Mn}$-oxide accumulation at $5.5 \mathrm{~cm}$, and decreased within the Fe-oxide layer below to $\sim 6 \mu \mathrm{g} \mathrm{g}^{-1}$. The subsequent $\mathrm{U}_{\mathrm{NL}}$ peak of $12 \mu \mathrm{g} \mathrm{g}^{-1}$ at $12 \mathrm{~cm}$ was located between the two major Fe/Mn accumulations. Deeper in the sediments, $\mathrm{U}_{\mathrm{NL}}$ contents according to eq. (6) steeply decreased and became ultimately non-existent within the buried Fe/Mn-oxide enrichment before increasing again to $5.5 \mu \mathrm{g} \mathrm{g}^{-1}$ at the bottom of the core. As in core $B$, high pore water $U$ concentrations prevailed at the depth of elevated $U_{N L}$ (and/or $U_{\text {auth }}$ ) contents below the $\mathrm{Fe} / \mathrm{Mn}$-oxide enrichment, where decreasing $\mathrm{SO}_{4}{ }^{2-}$ concentrations indicated sulphate-reducing conditions. Pore water $U$ concentrations were generally $<3 \mu \mathrm{g} \mathrm{I}^{-1}$ except for three prominent peaks above the upper Mn-oxide enrichment and on top and below the buried Fe/Mn accumulations. The hypothesized $U_{\text {auth }}$ content of up to $50 \%$ of the total particulate $U$ at the bottom of the core was concomitant with decreasing pore water Fe(II) and $\mathrm{Mn}$ (II) concentrations.

\subsection{Core $D$}


In core $\mathrm{D}, \mathrm{U}_{\mathrm{NL}}$ contents were comparatively high in the top $8 \mathrm{~cm}$ of the core, with $\sim 13 \mu \mathrm{g} \mathrm{g}^{-1}$ down to the upper, minor Fe-oxide accumulation. Deeper in the sediments, $U_{\mathrm{NL}}$ decreased steeply down to $\sim 3$ $\mu \mathrm{g} \mathrm{g}^{-1}$, with generally low contents interrupted only by a peak at $14 \mathrm{~cm}$, and even lower values of $\sim 0.5 \mu \mathrm{g} \mathrm{g}^{-1}$ within the buried Fe/Mn enrichment. Pore water $\mathrm{U}$ concentrations remained $<2.5 \mu \mathrm{g} \mathrm{I}{ }^{-1}$ from the upper Fe/Mn layer down to the $U_{N L}$ peak at $14 \mathrm{~cm}$. Within the deeper sediments, including the buried Fe/Mn layer, an increasing but unsteady trend was observed, reaching pore water $\mathrm{U}$ concentration of $>7 \mu \mathrm{g} \mathrm{I}^{-1}$ at the bottom of the core, where high TS contents occurred. This pore water $\mathrm{U}$ flux was directed upwards to the $\mathrm{U}_{\mathrm{NL}}$ peak at $14 \mathrm{~cm}$ where $\mathrm{SO}_{4}{ }^{2-}$ concentrations were at their minimum, indicating that the accumulation likely consisted of $U_{\text {auth. }}$ Varying contents of $U_{\text {auth }}$ could be expected further down the core, possibly reaching more than $50 \%$ of total particulate $\mathrm{U}$.

\subsection{Iron speciation}

Iron speciation analysis for the characterization of mineral Fe phases in the sediment cores A, C and partially in core B (Fig. 5), indicated that sedimentary Fe-oxides were composed of about $50 \%$ crystalline Fe-oxides [e.g. hematite $\left(\mathrm{Fe}_{2} \mathrm{O}_{3}\right)$ and goethite $\left.(\mathrm{FeOOH})\right], 35 \%$ amorphous Fe-oxides [e.g. ferrihydrite $\left.\left(\mathrm{Fe}_{2} \mathrm{O}_{3} \cdot 0.5 \mathrm{H}_{2} \mathrm{O}\right)\right]$ and about $15 \%$ magnetite $\left(\mathrm{Fe}_{3} \mathrm{O}_{4}\right)$. It also suggested that the brown color of the sediment, indicating $\mathrm{Fe}(\mathrm{III})$, was visible if there were at least 1.5 wt\% of $\mathrm{Fe}$ (oxyhydr)oxides (including hematite, goethite and ferrihydrite). Fe(II), which is involved in the formation of Fe-monosulphides, Fe-carbonates and Fe-phosphates in sedimentary environments, remained below $2 \%$ o throughout all sections of the core. The highest Fe(II) concentrations were found at the bottom of core A where high TS contents had been observed (see Fig. 2), suggesting the presence of Fe-sulphides. This $\mathrm{Fe}(\mathrm{II})$ peak was concomitant with a minor peak in $\mathrm{U}_{\mathrm{NL}}$ and minimum pore water $U$ concentrations. Phosphorus concentrations correlated well with total Fe and/or amorphous Fe-oxides whereby the P/Fe ratio was increased within the Fe-oxide enriched layers.

\section{Discussion}

\subsection{Mass balance and $U$ accumulation in sediments}


We estimated the deposition rate of $U$ in the sediments of Lake Baikal based on a mass balance using U loads reported in previous studies (Edgington et al., 1991, 1996; Falkner et al., 1997; Bobrov et al., 2001). In addition, there is an aeolian component, accounting for about $6 \%$ of the total particulate input (Lomonosov et al., 1995; Granina et al., 2000; Fagel et al., 2007), which is enriched in U with a concentration of $\sim 6 \mu \mathrm{g} \mathrm{g}^{-1}$ (Bobrov et al., 2001), adding over a ton of particulate $\mathrm{U}$ per year. Assuming that the particulate load leaving the lake through the Angara River is negligible, about $55 \mathrm{t}$ $\mathrm{U}$ are permanently buried in the sediment annually (see Table 1). Averaged over the surface area of the lake $\left(31^{\prime} 722 \mathrm{~km}^{2}\right)$, this translates to a mass accumulation rate (MAR) for $\mathrm{U}$ of $\sim 1.75 \mathrm{mg} \mathrm{m}^{-2} \mathrm{a}^{-1}$. Considering the sedimentation rates established for cores $A$ to $D\left(0.05\right.$ to $0.09 \mathrm{~cm} \mathrm{a}^{-1}$; Och et al., 2012), and assuming a sediment density of $2.6 \mathrm{~g} \mathrm{~cm}^{-3}, \mathrm{U}$ contents of $\sim 1.2 \mu \mathrm{g} \mathrm{g}$ are thus expected. Contents may be higher in the south basin than in the north and central basins as the bulk of particulate lithogenic $U$ is mainly deposited in the South Basin and within the Selenga Delta (Vologina and Sturm, 2009). Nonetheless, the estimated $1.2 \mu \mathrm{g} \mathrm{g}^{-1}$ were far below the values expected for the upper continental crust ( $2.8 \mu \mathrm{g} \mathrm{g}^{-1}$; Taylor and McLennan, 1995), and even further below the average $\mathrm{U}$ content in the granitoid rocks of the Mongolian-Transbaikalian Belt adjacent to the eastern shore of Lake Baikal (ca. $3.4 \mu \mathrm{g} \mathrm{g}^{-1}$; Jahn et al., 2009; Litvinovsky et al., 2011).

Based on these mass balance considerations alone, Lake Baikal sediments would be expected to be depleted in $U$ relative to the upper continental crust. However, $U$ contents measured in the present study average $13 \mu \mathrm{g} \mathrm{g}^{-1}$ with maxima of $>20 \mu \mathrm{g} \mathrm{g}^{-1}$ in the surface sediment, which is in accordance with previous studies (e.g. Chebykin et al., 2007). This discrepancy may be caused by the highly variable sedimentation rates that are difficult to determine precisely and, which on the Academician Ridge, can be as low as $0.002 \mathrm{~cm} \mathrm{a}^{-1}$ (Edgington et al., 1991; Appleby et al., 1998; Vologina et al., 2000, 2003; Granina et al., 2004 and references therein; Müller et al., 2005; Watanabe et al., 2009; Vologina and Sturm, 2009; Morgenstern et al., 2013). Alternatively, the mass budget calculations presented above are based on load data that must be considered with caution. Samples for the estimation of riverine $U$ load were collected during summer, when the lake and its tributaries were 
more easily accessible for sampling. The peak input of terrigenous material occurs in May after the ice break-up and major snow melt (Edgington et al., 1996; Falkner et al., 1997; Bobrov et al., 2001). Hence, we suspect that a more extensive sampling campaign throughout the year might provide the missing load and begin to close the gap in the dataset for $\mathrm{U}$ input into the lake.

\subsection{Uranium deposition}

In the present study we discuss the processes governing dissolution and precipitation of $U$ bearing particles and minerals between the water column and the deeper sediments. In this context, substantial sedimentary $U$ enrichments may result from either (1) diffusive $U$ flux from the bottom water into the sediment (Klinkhammer and Palmer, 1991; Chaillou et al., 2002; McManus et al., 2005; Morford et al., 2009a, b), (2) accumulation of $U$ associated with particulate organic matter, so-called non-lithogenic or bio-authigenic U (Anderson, 1982; Knauss and Ku, 1983; Anderson et al., 1998; Zheng et al., 2002a; McManus et al., 2005), (3) the association of $U$ with other settling particles, such as Fe(III)- and Mn(IV)-oxides (Hsi and Langmuir, 1985; Barnes and Cochran, 1993; Sani et al., 2004), or (4) a combination of all the above. As reported by Chebykin et al. (2010), the scavenging of $U$ by particulate matter occurs in the water column of Lake Baikal, as $U$ is significantly enriched in pelagic suspended matter in comparison with riverine material. This is likely due to a decrease in the concentration of dissolved complexing agents as rivers enter the lake (Edgington et al., 1996, 1997), exemplified by a several fold decrease in dissolved organic matter between riverine and lacustrine water masses (Yoshioka et al., 2002).

Good correlation between $U_{\mathrm{NL}}$ and the export flux of organic carbon to the sediment has been shown for marine (Anderson et al., 1998; Zheng et al., 2002b; McManus et al., 2005) and lacustrine environments (Chappaz et al., 2010). This suggests that particulate non-lithogenic U (PNU) associated with settling organic matter might play an important role for $U$ scavenging in aquatic systems. Moreover, Zheng et al. (2002a) found that up to 70\% of deposited PNU were buried within anoxic marine sediments. In the present study, the profiles of $U_{\mathrm{NL} \text {-auth, }}$ i.e. non-lithogenic $U$ without 
estimated, newly added authigenic $U$ (see Fig. 4), and total organic carbon (TOC) did not correlate well along the analysed depth profile except for a short interval between the uppermost few centimetres and the uppermost $\mathrm{Fe} / \mathrm{Mn}$ accumulations in cores $\mathrm{A}$ and $\mathrm{D}$ and to a lesser extent in core C. This is not necessarily surprising since correlation between $U$ and organic matter concentrations can vary significantly within natural samples (Cumberland et al., 1016). However, a broadly positive covariation between the MARs of $\mathrm{U}_{\mathrm{NL}}$ and TOC, although based on a very limited dataset, is consistent with association of $U$ with settling organic matter to some degree (see Fig. 6). $\mathrm{C} / \mathrm{N}$ ratios within the uppermost (oxic) sediment layer negatively correlated with the MAR of $U_{N L}$. As lower $C / N$ values suggest a higher contribution from allochthonous organic matter (e.g. Meyers and Ishiwatari, 1993), the negative relationship with $U_{N L}$ MARs suggests that the association of $U$ with organic matter, if at all, primarily occurred in the lake and not in the watershed. Hence, that ambiguous connection between the $\mathrm{U}_{\mathrm{NL}-\text { auth }}$ and TOC profiles possibly arose from the greater proportion of allochthonous organic matter in the lake as opposed to the ocean. Regarding a potential association of biosiliceous phytoplankton with $\mathrm{U}_{\mathrm{NL}}$, longer sediment cores from Lake Baikal showed that elevated U concentrations were concomitant with higher counts of diatoms (Gavshin et al., 1994; Edgington et al., 1996; Goldberg et al., 2005), and it was hypothesized that $U$ accumulated in diatom frustules. This was, however, rejected by Goldberg et al. (1998), and the similarity in the profiles of $U$ and diatom counts was compellingly accounted for by the effects of glacial-interglacial cycles on both riverine input and primary productivity (Edgington et al., 1996; 1997; Chebykin et al., 2004). Furthermore, it was previously suggested that some $U$ in the water column of Lake Baikal adsorbed onto particulate surfaces such as Fe-hydroxide coatings (Edgington et al., 1996; Falkner et al., 1997; see also Chebykin et al., 2010). However, we did not find a correlation between the MARs of Fe and $\mathrm{U}$ calculated from the concentrations at the top of the analysed sediment cores, and the respective geochemical profiles suggested that the association between Fe and $U$ might be secondary.

In summary, while $U$ was enriched in the lake, the precise carrier phase for $U$ from the water column to the sediment remains unclear and might include a combination of organic matter, Fe-oxides and 
clay particles (e.g. Duff et al., 2002). Despite the high $\mathrm{O}_{2}$ concentrations in the lake and comparatively deep penetration depths into the sediment, $U$ was remobilized very slowly.. This is in contrast to other studies stating that oxidative $U$ remobilization from lake sediments is a very fast process (Cochran et al., 1986; Anderson et al., 1989). Hence, this suggests that high amounts of reactive $U$ are retained in the Baikal sediment long enough for early diagenetic redistribution.

\subsection{The diagenetic cycle of uranium}

The thickness of the oxic layer of aquatic sediments defines the rate of exchange of dissolved redoxsensitive metal species between the bottom waters and the deeper anoxic sediment. The main rate determining parameters are molecular diffusion gradients, metal release rates following the oxidation of organic matter, and bioturbation. Within the $\mathrm{O}_{2}$-containing zone of Baikal sediments, i.e. between the sediment water-interface and the $\mathrm{O}_{2} / \mathrm{Mn}$ (II) redox boundary (see Fig. 2), $\mathrm{U}_{\mathrm{M}}$ contents were relatively constant with values of $\sim 15 \mu \mathrm{g} \mathrm{g}^{-1}$. The uppermost sample of core A containing $>20$ $\mu \mathrm{g} \mathrm{g}^{-1} \mathrm{U}$ was an exception. While similar $\mathrm{U}_{\mathrm{M}}$ contents extended deeper into the sediments and decreased only at or below the upper Fe-oxide enrichment, $\mathrm{U}_{\mathrm{NL}}$ contents exhibited an overall decrease, although with some variations, from the sediment-water interface down to the buried Fe(and $\mathrm{Mn}$-) oxide accumulations. The occasional $\mathrm{U}_{\mathrm{NL}}$ peaks that occurred deeper in the sediment were interpreted to represent sediment layers where $U_{\text {auth }}$ was formed (see section 4.3). A common feature in cores $\mathrm{A}$ and $\mathrm{C}$ was that the buried Fe/Mn enrichments occurred underneath an interval of greyish sediment, indicative of minimal amounts of reducible Fe-oxides (see Fig. 5), whereas cores B and $\mathrm{D}$ exhibited brown sediment between both Fe/Mn enrichments (see Fig. 2). In addition, the relatively constant pore water $\mathrm{U}$ concentration within the uppermost 15 to $20 \mathrm{~cm}$ in cores $\mathrm{B}$ and $\mathrm{D}$ was below the solubility of $\mathrm{U}$ at reducing conditions, i.e. $<2.5 \mu \mathrm{g} \mathrm{I^{-1 }}$ for amorphous $\mathrm{UO}_{2} \cdot \mathrm{xH}_{2} \mathrm{O}$, and $<0.5 \mu \mathrm{g} \mathrm{I}^{-1}$ for crystal $\mathrm{UO}_{2}$ at $\mathrm{pH}>4$ (e.g. Rai et al. 1990; Nagao et al., 2002). Hence, it appeared that more dynamic redox cycling with steeper Eh gradients prevailed in core $C$ and particularly in core $A$, leading to an enhanced remobilization of $\mathrm{U}$ associated with Fe-oxides and/or organic matter (Hsi and Langmuir, 1985; Duff et al., 2002; Sherman et al., 2008; Morford et al., 2009a, b). Bioturbation, which 
could significantly accelerate the remobilization of $U$ in sediments (Zheng et al., 2002b; Lagauzère et al., 2013), was not observed in cores A to D, and previous studies suggested that it likely has a limited effect on sediment mixing in the deeper parts of Lake Baikal (Martin et al., 2005).

\subsection{Uranium remobilization by reductive dissolution of Fe- and Mn-oxides}

In the absence of high concentrations of complexing ligands such as carbonate, oxalate, hydroxide, fulvic and humic acids (e.g. Lenhart et al., 2000; Wazne et al., 2003; Guillaumont et al., 2003; Grenthe et al., 2004), dissolved $\mathrm{U}(\mathrm{VI})$ readily adsorbs onto and/or co-precipitates with Fe-oxides such as ferrihydrite, hematite and goethite (Hsi and Langmuir, 1985; Waite et al., 1994; Lenhart and Honeyman, 1999; Duff et al., 2002; Wazne et al., 2003; Nico et al., 2009; Kelly, 2010; Vodyanitskii, 2011; Li and Kaplan, 2012; Cumberland et al., 2016) and Mn-oxides (e.g. Al-Attar and Dyer, 2002; Misaelides et al., 2002; Webb et al., 2006; Wang et al., 2012). This can lead to immobilization of U(VI) in the sediment, as demonstrated by the $U$ speciation model outlined in section 4.2 , and inhibit further bacterial reduction (Ortiz-Bernad et al., 2004; Boland et al., 2011). Considering the high contents of Fe-oxides in Lake Baikal, $U$ association with Fe-oxide phases might indeed be an important aspect leading to its accumulation and resilience in the sediment under oxic to suboxic conditions. The diagenetic cycles of Fe- and Mn-oxides, on the other hand, are unlikely to exert significant direct influence on the U diagenetic cycle (Klinkhammer and Palmer, 1991), other than the release of $U$ during the reductive dissolution of $\mathrm{Fe}$ - and $\mathrm{Mn}$-oxides. The Fe speciation data demonstrated that a coupling of $\mathrm{U}(\mathrm{VI})$ to Fe-oxide particles in the water column could be retained within amorphous and especially crystalline Fe-oxides throughout the studied sediment sections. While $\mathrm{U}(\mathrm{VI})$ initially adsorbed to e.g. nanoparticulate ferrihydrite in the water column and/or at the sediment surface, the Fe-U coupling might have been stabilized by the transformation to crystalline Fe-oxides. Under the given temperature-pH conditions and disregarding organic complexation, this could have occurred within a few years (Schwertmann et al., 2004). Note, however, that this transformation in Lake Baikal sediments was likely slowed down by the presence of high pore water phosphate concentrations (see section 5.5; Och et al., 2012). The partial preservation and slow 
dissolution of these precipitates at depth might explain the high pore water $U$ concentrations within the reducing sediment intervals, even below the buried Fe-oxide layers. This explanation presumes that the reaction kinetics for the reductive precipitation of $U_{\text {auth, }}$, i.e. the transformation of $U(V I)$ to $\mathrm{U}(\mathrm{IV})$, are slower than for the reductive dissolution of Fe-oxides, sustaining pore water $\mathrm{U}$ concentrations above the solubility of solid U(IV) phases. This is likely due to the formation of Ca$\mathrm{UO}_{2}-\mathrm{CO}_{3}$ complexes, which probably become more significant with depth along with rising $\mathrm{HCO}_{3}{ }^{-}$ concentrations partially fuelled by the reductive dissolution of Fe- and $\mathrm{Mn}$-oxides.

Not only Fe-oxide, but also Mn-oxide surfaces participate in $\mathrm{U}$ adsorption and sequestration (Webb et al., 2006; Wang et al., 2012). In the studied cores, the main particulate Mn species birnessite and todorokite (Och et al., 2012) are both known to adsorb U (Misaelides et al., 2002; Al-Attar and Dyer, 2002), but they occurred at far lower contents than Fe-oxides. In addition, they are considered to be much more reactive under reducing conditions than crystalline Fe-oxides (Och et al., 2012), and thus were likely a quantitatively less important carrier phase for $U$ in deeper, reducing sediments of Lake Baikal.

\subsection{The relationship between uranium and phosphorus}

The affinity of $U$ to be incorporated into phosphate minerals, with the potential to form stable uranyl phosphate minerals (Jerden and Sinha, 2003; Ohnuki et al., 2004; Wellman et al., 2007), can lead to highly elevated $\mathrm{U}$ contents (up to $250 \mu \mathrm{g} \mathrm{g}^{-1}$; Altschuler et al., 1958; Bird, 2012). Indeed, previous geochemical analysis of Lake Baikal sediments showed that intervals enriched in phosphate minerals (especially vivianite) exhibit $U$ concentrations of up to $90 \mathrm{\mu g} \mathrm{g}^{-1}$ (Zhmodik et al., 2003; 2005; see also Fagel et al., 2005), at least one order of magnitude higher than in most marine sediments (Plank and Langmuir, 1998). Hence, $U$ association with phosphate minerals can further $U$ enrichment. However, the very good correlation between total Fe and P contents $\left(R^{2}>0.96, p<0.001\right.$; see Fig. 5 and Och et al., 2012) indicates that in the studied cores, most of the $P$ and Fe enrichments result from enrichments of Fe (oxyhydr)oxides with adsorbed phosphate and/or Fe(II)-phosphates like vivianite. While we did not perform detailed mineralogical analyses of these layers, both vivianite and Fe 
(oxyhydr)oxides would contribute to the sum of extracted Fe-oxide phases (Fig. 5) and would explain the excellent correlation between sedimentary $\mathrm{P}$ and Fe. The preservation of substantial amounts of amorphous Fe (oxyhydr)oxides in the Fe-rich layers (see Fig. 5) despite their usually fast aging and crystallisation kinetics (Schwertmann et al., 2004) can be explained by the inhibition of this transformation if Fe (oxyhydr)oxides contain large amounts of adsorbed P (Galvez et al., 1999; see also März et al., 2012). Hence, while U was released into the pore water upon the dissolution of amorphous Fe-oxides/Fe(III)-phosphates, it was not trapped and enriched by re-adsorption and/or co-precipitation with the same phases. While average $\mathrm{P} / \mathrm{Fe}$ (wt\%/wt\%) ratios in the sediment and the MTB rocks were both 0.056 (Litvinowsky et al., 2011), Fe and P were enriched by a factor of 3 in the sediment. It is, therefore, conceivable that $\mathrm{Fe}$ and $\mathrm{P}$ minerals exerted a stabilizing effect on particulate $U$.

\subsection{Uranium diffusion across the sediment-water interface}

The pore water profiles of $U$ showed an increase from the bottom water down to the limit of $\mathrm{O}_{2}$ penetration (the $\mathrm{O}_{2} / \mathrm{Mn}(\mathrm{II})$ redox boundary). This increase was very well correlated with pore water Fe (with $\mathrm{R}^{2}$ around or higher than 0.9 ), indicating that they predominantly occurred in colloidal form (e.g. Lead and Wilkinson, 2006; Cumberland et al., 2016 and references therein). This was confirmed by the analysis of Lake Baikal sediment pore water with a portable capillary electrophoresis instrument, which discriminated colloidal Fe(III) in the measurement (Torres et al., 2014). These experiments showed that $\mathrm{Fe}$ detected in $0.45 \mu \mathrm{m}$-filtered pore water by atomic absorption spectroscopy was not $\mathrm{Fe}$ (II) but rather consisted of Fe(III) colloids that passed through the filter membrane. In order to evaluate whether dissolved $U$ diffused across the sediment-water interface and precipitated as $\mathrm{U}_{\text {auth }}$ deeper in the reducing part of the sediment, in the form of $\mathrm{UO}_{2}, \mathrm{U}_{3} \mathrm{O}_{7}$ or $\mathrm{U}_{3} \mathrm{O}_{8}$ (e.g. Klinkhammer and Palmer, 1991; Crusius et al., 1996; Zheng et al., 2000; Morford et al., 2001, 2009a, b; Chaillou et al., 2002; McManus et al., 2005), we normalized pore water U to Sc, which predominantly occurs in particulate form and is not redox-sensitive (Orians and Merrin, 2009). Figure 2 shows that pore water $\mathrm{U} / \mathrm{Sc}$ ratios were quite constant downcore and only increased below 
the buried $\mathrm{Fe} / \mathrm{Mn}$ layer in core $\mathrm{B}$ and in the reducing zone of core $\mathrm{C}$. Increases in the $\mathrm{U} / \mathrm{Sc}$ ratio coincided with the presence of authigenic $U$ (see Fig. 2 and 4) indicating the occurrence of diagenetic reactions of $U$ independent of the fate of Sc that lead to precipitation or associations with different mineral phases.

\subsection{The authigenic precipitation of uranium}

We can divide the core segments into intervals where $U$ was remobilized, e.g. through reductive dissolution of Fe- and/or Mn-oxides, and where $U$ precipitated, most likely through microbial mediation. As mentioned in section 4.3, the overall downward decrease of particulate $U$ was interrupted by peaks that likely represented $\mathrm{U}_{\text {auth }}$ formation, indicated by the diffusive fluxes directed towards the enrichments (see Fig. 2 and 4). In core B, estimation of the upward diffusive $U$ flux towards the $U_{N L} / U_{\text {auth }}$ peak at $21 \mathrm{~cm}$ depth using equations (3) to (6) resulted in 1.6 to $2.2 \mathrm{mg} \mathrm{m}^{-2} \mathrm{a}^{-1}$, depending on the ratio of $\mathrm{UO}_{2} \mathrm{CO}_{3}$ to $\mathrm{Ca}_{2} \mathrm{UO}_{2}\left(\mathrm{CO}_{3}\right)_{3}$. The solid phase $\mathrm{U}$ dissolution rate at the depth of maximum pore water $U$, adding up- and downward fluxes, was between 2.5 and $3.5 \mathrm{mg} \mathrm{m}^{-2} \mathrm{a}^{-1}$. Assuming a constant $U$ flux towards the hypothesized $U_{\text {auth }}$ enrichment at $20-25 \mathrm{~cm}$ depth (Fig. 2 and 4), which was estimated to contain $0.15 \mathrm{~g} \mathrm{~m}^{-2}$, resulted in an accumulation time of 65 - 90 years. In core $\mathrm{C}$, we calculated a pore water $\mathrm{U}$ flux of $0.68-0.96 \mathrm{mg} \mathrm{m}^{-2} \mathrm{a}^{-1}$ from the peak of $\sim 10 \mu \mathrm{g} \mathrm{I}^{-1}$ at 14 $\mathrm{cm}$ directed towards the $U_{\mathrm{NL}}$ peak at $12 \mathrm{~cm}$. This $U_{\mathrm{NL}}$ peak was likely composed of $U_{\text {auth }}$ fed by the diffusive $U$ flux (Fig. 2). Hence, assuming an enrichment of $U_{\text {auth }}$ between $10-14 \mathrm{~cm}$ resulting in a deposition of $\sim 0.14 \mathrm{~g} \mathrm{~m}^{-2}$ and a constant diffusive flux, the estimated accumulation time here was 140-200 years. Therefore, the timeframes for the enrichments of $U_{\text {auth }}$ in cores $B$ and $C$ matched well with the chronology of the burial of the lower, buried Fe/Mn accumulations, i.e. their decoupling from the dynamic redox cycling at the $\mathrm{O}_{2} / \mathrm{Mn}$ (II) boundary, and the onset of the precipitation of the upper Fe/Mn layer starting more than 200 years ago (Och et al., 2012). This suggests that the diagenetic accumulation of $U_{\text {auth }}$ tends to occur once two Fe/Mn oxide layers have formed.

The pore water profiles of $\mathrm{Fe}, \mathrm{Mn}$ and $\mathrm{SO}_{4}{ }^{2-}$ were used to refine the sedimentary redox stratification. All cores exhibited the highest pore water $\mathrm{U}$ concentrations within intervals characterized by $\mathrm{SO}_{4}{ }^{2-}$ 
reduction, with values clearly exceeding the solubility for amorphous and crystalline $\mathrm{UO}_{2}$ within anoxic sediment (e.g. Rai et al., 1990; Nagao et al., 2002). Elevated U contents in anoxic sediment, such as those observed between both Fe-oxide accumulations and at the bottom of core A, have been described in marine sediments (Zhorov et al., 1982; Cochran et al., 1986; Anderson et al., 1989; Chaillou et al., 2002; Audry et al., 2006). The presence of dissolved U(VI) in anoxic sediment was frequently attributed to sampling artefacts, such as re-oxygenation of particulate $U(I V)$ to dissolved U(VI) during sampling (e.g. Anderson et al., 1989) or colloidal U (e.g. Chaillou et al., 2002). While the latter probably occurred within the oxic interval of the Lake Baikal cores (see chapter 5.7), the accumulation of $U_{\text {auth }}$ close to pore water $U$ maxima suggested that no $U(I V)$ re-oxygenation occurred within the sampled anoxic sediments. Pore water concentrations were truly increased and might originate from rising levels of $\mathrm{HCO}_{3}{ }^{-}$generated by the reductive dissolution of Fe- and $\mathrm{Mn}$-oxides, which would increase the solubility of $U$ due to the formation of carbonate complexes.

While it is generally conceivable that Fe-monosulphides reduced dissolved $\mathrm{U}(\mathrm{VI})$ to insoluble $\mathrm{U}(\mathrm{IV})$ (e.g. Hua and Deng, 2008; Bargar et al., 2013), this is unlikely to be a major mechanism leading to the accumulation of $U_{\text {auth }}$ in Lake Baikal sediments. Comparatively high Fe-monosulphide contents around $10 \mathrm{~cm}$ depth in core $A$ corresponded to only modest $U_{\text {auth }}$ enrichments, while very minor amounts of Fe-monosulphides occurred in core $\mathrm{C}$ where we suspect the most pronounced $\mathrm{U}_{\text {auth }}$ accumulation at $12 \mathrm{~cm}$ depth.

\section{Conclusions}

For a pervasively oxic lacustrine system, the high uranium concentrations in Lake Baikal sediments are, to date, unparalleled. The mass balance considerations outlined in the present study, however, reveal a significant gap regarding the supply of $U$ into the lake and more frequent sampling of the tributaries to Lake Baikal, in particular right after the ice break-up in May, and a better appreciation of uranium deposits situated within the Lake Baikal watershed is needed to deliver a more detailed appreciation of its elemental budget. Nonetheless, the mechanisms leading to much of the $U$ being 
retained within the sediment is likely the adsorption within the water column of dissolved $U$, or rather non-lithogenic $U$, onto particulate matter such as organic matter and metal oxides. The diagenetic remobilization of $U$ is mainly limited to the release of non-lithogenic $U$ through the oxidation of organic matter, and the reduction of Fe-oxides and, to a lesser extent, Mn-oxides. Most diagenetically removed $U$ likely re-precipitates as authigenic $U$ by bacterial mediation in the sediment that is relatively rich in organic carbon. Therefore, little of this $U$ is delivered back to the water column. However, the abundance of refractory Fe-P-phases within the sediments of Lake Baikal may also play an important role in retaining high $U$ contents despite dynamic redox cycling down to a few decimetres below the sediment-water interface. Admittedly, some important questions remain unanswered regarding elevated sedimentary $U$ concentrations in Lake Baikal. The hypothesis presented here, such as the division into three $U$ pools $\left(U_{L}, U_{N L}\right.$ and $\left.U_{\text {auth }}\right)$, will have to be tested through a more thorough sampling of lake water and sediments as well as mineralogical studies where possible. But certainly, future research on the global $U$ cycle in the past and present will have to take into account that even well oxygenated environments can act as a sizeable $U$ sink under certain conditions.

\section{Acknowledgement}

We acknowledge the help of Benoit Pernet-Coudrier and Joanne Favre-Bulle for sampling and on-site measurements. Many thanks go to Ruslan Gnatovsky (LIN) for support as co-leader during the expedition on the lake, and to the Captain and Crew of RV Vereshagin. The project was made possible by the Swiss National Science Foundation Grant no. 200021_124411.

\section{References}

Agafonov, B.P., 1990. Exolitodynamics of Baikal rift zone, Novosibirsk, p. 176.

Al-Attar, L., Dyer, A., 2002. Sorption behaviour of uranium on birnessite, a layered manganese oxide. Journal of Materials Chemistry 12, 1381-1386. 
Altschuler, Z.S., Clarke, R.S., Young, E.J., 1958. Geochemistry of uranium in apatite and phosphorite. US Government Printing Office, Washington, pp. 45-90.

Andersen, M.B., Vance, D., Morford, J.L., Bura-Nakić, E., Breitenbach, S.F.M., Och, L., 2016. Closing in on the marine $238 \mathrm{U} / 235 \mathrm{U}$ budget. Chemical Geology 420, 11-22.

Anderson, R.F., 1982. Concentration, vertical flux, and remineralization of particulate uranium in seawater. Geochimica et Cosmochimica Acta 46, 1293-1299.

Anderson, R.F., Fleisher, M.Q., LeHuray, A.P., 1989. Concentration, oxidation state, and particulate flux of uranium in the Black Sea. Geochimica et Cosmochimica Acta 53, 2215-2224.

Anderson, R.F., Kumar, N., Mortlock, R.A., Froelich, P.N., Kubik, P., Dittrich-Hannen, B., Suter, M., 1998. Late-Quaternary changes in productivity of the Southern Ocean. Journal of Marine Systems 17, 497-514.

Appleby, P.G., Flower, R.J., Mackay, A.W., Rose, N.L., 1998. Paleolimnological assessment of recent environmental change in Lake Baikal: sediment chronology. Journal of Paleolimnology 20, 119-133.

Audry, S., Blanc, G., Schäfer, J., Chaillou, G., Robert, S., 2006. Early diagenesis of trace metals (Cd, Cu, $\mathrm{Co}, \mathrm{Ni}, \mathrm{U}, \mathrm{Mo}$, and $\mathrm{V}$ ) in the freshwater reaches of a macrotidal estuary. Geochimica et Cosmochimica Acta 70, 2264-2282.

Audry, S., Schäfer, J., Blanc, G., Jouanneau, J.-M., 2004. Fifty-year sedimentary record of heavy metal pollution ( $\mathrm{Cd}, \mathrm{Zn}, \mathrm{Cu}, \mathrm{Pb})$ in the Lot River reservoirs (France). Environmental Pollution, 132(3): 413-426.

Bargar, J.R., Reitmeyer, R., Lenhart, J.J., Davis, J.A., 2000. Characterization of U(VI)-carbonato ternary complexes on hematite: EXAFS and electrophoretic mobility measurements. Geochimica et Cosmochimica Acta 64, 2737-2749.

Bargar, J.R., Williams, K.H., Campbell, K.M., Long, P.E., Stubbs, J.E., Suvorova, E.I., Lezama-Pacheco, J.S., Alessi, D.S., Stylo, M., Webb, S.M., Davis, J.A., Giammar, D.E., Blue, L.Y., Bernier-Latmani, 
R., 2013. Uranium redox transition pathways in acetate-amended sediments. Proceedings of the National Academy of Sciences 110, 4506-4511.

Barnes, C.E., Cochran, J.K., 1993. Uranium geochemistry in estuarine sediments: Controls on removal and release processes. Geochimica et Cosmochimica Acta 57, 555-569.

Berner, R.A., 1980. Early diagenesis: A theoretical approach. Princeton University Press.

Bird, G.A., 2012. Uranium in the Environment: Behavior and Toxicity, in: Meyers, R.A. (Ed.), Encyclopedia of Sustainability Science and Technology. Springer New York, pp. 11220-11262.

Bobrov, V.A., Granina, L.Z., Kolmogorov, Y.P., Melgunov, M.S., 2001. Minor elements in aeolian and riverine suspended particles in Baikal Region. Nuclear Instruments and Methods in Physics Research Section A: Accelerators, Spectrometers, Detectors and Associated Equipment 470, 431-436.

Boland, D.D., Collins, R.N., Payne, T.E., Waite, T.D., 2011. Effect of Amorphous Fe(III) Oxide Transformation on the Fe(II)-Mediated Reduction of U(VI). Environmental Science \& Technology 45, 1327-1333.

Brennecka, G.A., Herrmann, A.D., Algeo, T.J., Anbar, A.D., 2011. Rapid expansion of oceanic anoxia immediately before the end-Permian mass extinction. Proceedings of the National Academy of Sciences 108, 17631-17634.

Brooks, S.C., Fredrickson, J.K., Carroll, S.L., Kennedy, D.W., Zachara, J.M., Plymale, A.E., Kelly, S.D., Kemner, K.M., Fendorf, S., 2003. Inhibition of Bacterial U(VI) Reduction by Calcium. Environmental Science \& Technology 37, 1850-1858.

Brunello, A.J., Molotov, V.C., Dugherkhuu, B., Goldman, C., Khamaganova, E., Strijhova, T., Sigman, R., 2006. Lake Baikal. Experiences and Lessons Learned Brief, Tahoe-Baikal Institute, South Lake Tahoe, CA, USA.

Calvert, S.E., Pedersen, T.F., 1993. Geochemistry of Recent oxic and anoxic marine sediments: Implications for the geological record. Marine Geology 113, 67-88. 
Chaillou, G., Anschutz, P., Lavaux, G., Schäfer, J., Blanc, G., 2002. The distribution of Mo, U, and Cd in relation to major redox species in muddy sediments of the Bay of Biscay. Marine Chemistry 80, 41-59.

Chappaz, A., Gobeil, C., Tessier, A., 2010. Controls on uranium distribution in lake sediments. Geochimica et Cosmochimica Acta 74, 203-214.

Chebykin, E.P., Edgington, D.N., Goldberg, E.L., Phedorin, M.A., Kulikova, N.S., Zheleznyakova, T.O., Vorobyova, S.S., Khlystov, O.M., Levina, O.V., Ziborova, G.A., Grachev, M.A., 2004. Uraniumseries isotopes as proxies of Late Pleistocene climate and geochronometers in bottom sediments of Lake Baikal. Russian Geology and Geophysics 45, 539-556.

Chebykin, E.P., Goldberg, E.L., Kulikova, N.S., 2010. Elemental composition of suspended particles from the surface waters of Lake Baikal in the zone affected by the Selenga River. Russian Geology and Geophysics 51, 1126-1132.

Chebykin, E.P., Goldberg, E.L., Kulikova, N.S., Zhuchenko, N.A., Stepanova, O.G., Malopevnaya, Y.A., 2007. A method for determination of the isotopic composition of authigenic uranium in Baikal bottom sediments. Russian Geology and Geophysics 48, 468-477.

Cochran, J.K., Carey, A.E., Sholkovitz, E.R., Surprenant, L.D., 1986. The geochemistry of uranium and thorium in coastal marine sediments and sediment pore waters. Geochimica et Cosmochimica Acta 50, 663-680.

Condie, K.C., 1993. Chemical composition and evolution of the upper continental crust: Contrasting results from surface samples and shales. Chemical Geology 104, 1-37.

Crusius, J., Calvert, S., Pedersen, T., Sage, D., 1996. Rhenium and Molybdenum Enrichments in Sediments as Indicators of Oxic, Suboxic and Sulfidic Conditions of Deposition. Earth Planet. Sci. Lett. $145,65--78$.

Cumberland, S.A., Douglas, G., Grice, K., Moreau, J.W., 2016. Uranium mobility in organic matter-rich sediments: A review of geological and geochemical processes. Earth-Science Reviews 159, 160-185. 
De Groot, A.J., 1995. Metal and sediments: A global perspective. In: Allen, H.E. (Ed.), Metal

Contaminated Aquatic Sediments. Ann Arbor Press, pp. 1-20.

Doynikova, O.A., Tarasov, N.N., Mokhov, A.V., 2014. A new phosphatic type of uranium deposits in Russia. Doklady Earth Sciences, 457(2): 910-914.

Duff, M.C., Coughlin, J.U., Hunter, D.B., 2002. Uranium co-precipitation with iron oxide minerals. Geochimica et Cosmochimica Acta 66, 3533-3547.

Dunk, R.M., Mills, R.A., Jenkins, W.J., 2002. A reevaluation of the oceanic uranium budget for the Holocene. Chemical Geology 190, 45-67.

Dzombak, D. A., Morel F. M. M., 1990. Surface complexation modelling. Wiley Interscience.

Edgington, D.N., Klump, J.V., Robbins, J.A., Kusner, Y.S., Pampura, V.D., Sandimirov, I.V., 1991. Sedimentation rates, residence times and radionuclide inventories in Lake Baikal from 137Cs and $210 \mathrm{~Pb}$ in sediment cores. Nature $350,601-604$.

Edgington, D.N., Robbins, J.A., Colman, S.M., Orlandini, K.A., Gustin, M.P., 1996. Uranium-series disequilibrium, sedimentation, diatom frustules, and paleoclimate change in Lake Baikal. Earth and Planetary Science Letters 142, 29-42.

Edgington, D.N., Robbins, J.A., Colman, S.M., Orlandini, K.A., Gustin, M.P., Klump, J.V., Granina, L.Z., 1997. Reply to the Comment by R. Anderson on "Uranium-series disequilibrium, sedimentation, diatom frustules, and paleoclimate change in Lake Baikal”. Earth and Planetary Science Letters 148, 399-404.

Fagel, N., Alleman, L.Y., Granina, L., Hatert, F., Thamo-Bozso, E., Cloots, R., André, L., 2005. Vivianite formation and distribution in Lake Baikal sediments. Global and Planetary Change 46, 315336.

Fagel, N., Thamó-Bózsó, E., Heim, B., 2007. Mineralogical signatures of Lake Baikal sediments: Sources of sediment supplies through Late Quaternary. Sedimentary Geology 194, 37-59.

Falkner, K.K., Church, M., Measures, C.I., LeBaron, G., Thouron, D., Jeandel, C., Stordal, M.C., Gill, G.A., Mortlock, R., Froelich, P., Chan, L.H., 1997. Minor and Trace Element Chemistry of Lake 
Baikal, Its Tributaries, and Surrounding Hot Springs. Limnology and Oceanography 42, 329345.

Falkner, K.K., Measures, C.I., Herbelin, S.E., Edmond, J.M., Weiss, R.F., 1991. The Major and Minor Element Geochemistry of Lake Baikal. Limnology and Oceanography 36, 413-423.

Fox, P.M., Davis, J.A., Zachara, J.M., 2006. The effect of calcium on aqueous uranium(VI) speciation and adsorption to ferrihydrite and quartz. Geochimica et Cosmochimica Acta 70, 1379-1387.

Galvez, N., Barron, V., Torrent, J., 1999. Effect of phosphate on the crystallization of hematite, goethite, and lepidocrocite from ferrihydrite. Clays and Clay Minerals, 47(3): 304-311.

Gavshin, V., Bobrov, V., Bogdanov, Y.A., 1994. Uranium anomalies in Lake Baikal deep-water sediments. Dokl. RAN 334, 356-359.

Ginder-Vogel, M., Criddle, C.S., Fendorf, S., 2006. Thermodynamic Constraints on the Oxidation of Biogenic UO2 by Fe(III) (Hydr)oxides. Environmental Science \& Technology 40, 3544-3550.

Goldberg, E.D., Koide, M., Schmitt, R.A., Smith, R.H., 1963. Rare-earth distributions in the marine environment. Journal of Geophysical Research 68, 4209-4217.

Goldberg, E.L., Chebykin, E.P., Vorob'eva, S.S., Grachev, M.A., 2005. Uranium signals of paleoclimate humidity recorded in sediments of Lake Baikal. Doklady Earth Sciences 400, 52-56

Goldberg, E.L., Grachev, M.A., Bobrov, V.A., Bessergenev, A.V., Zolotaryov, B.V., Likhoshway, Y.V., 1998. Do diatom algae frustules accumulate uranium? Nuclear Instruments and Methods in Physics Research Section A: Accelerators, Spectrometers, Detectors and Associated Equipment 405, 584-589.

Goldberg, T., Archer, C., Vance, D., Thamdrup, B., McAnena, A., Poulton, S.W., 2012. Controls on Mo isotope fractionations in a Mn-rich anoxic marine sediment, Gullmar Fjord, Sweden. Chemical Geology 296-297, 73-82.

Granina, L., Mueller, B., Wehrli, B., Martin, P., 2000. Oxygen, iron, and manganese at the sedimentwater interface in Lake Baikal. Terra Nostra 9, 87-94. 
Granina, L., Müller, B., Wehrli, B., 2004. Origin and dynamics of Fe and Mn sedimentary layers in Lake Baikal. Chemical Geology 205, 55-72.

Grenthe, I., Fuger, J., Konings, R.J.M., Lemire, R.J., Muller, A.B., Nguyen-Trung Cregu, C., Wanner, H., 2004. Chemical Thermodynamics of Uranium. OECD Nuclear Energy Agency, Issy-lesMoulineaux, France.

Guillaumont, R., Fanghanel, T., Neck, V., Fuger, J., Palmer, D.A., Grenthe, I., Rand, M.H., 2003. Update on the chemical thermodynamics of uranium, neptunium, plutonium, americium and technetium. Elsevier, Amsterdam.

Heim, B., Oberhaensli, H., Fietz, S., Kaufmann, H., 2005. Variation in Lake Baikal's phytoplankton distribution and fluvial input assessed by SeaWiFS satellite data. Global and Planetary Change $46,9-27$.

Hirose, K., Sugimura, Y., 1991. Chemical speciation of particulate uranium in seawater. Journal of Radioanalytical and Nuclear Chemistry 149, 83-96.

Hsi, C.-k.D., Langmuir, D., 1985. Adsorption of uranyl onto ferric oxyhydroxides: Application of the surface complexation site-binding model. Geochimica et Cosmochimica Acta 49, 1931-1941.

Hua, B., Deng, B., 2008. Reductive Immobilization of Uranium(VI) by Amorphous Iron Sulfide. Environmental Science \& Technology 42, 8703-8708.

Hutchinson, D.R., Golmshtok, A.J., Zonenshain, L.P., Moore, T.C., Scholz, C.A., Klitgord, K.D., 1992. Depositional and tectonic framework of the rift basins of Lake Baikal from multichannel seismic data. Geology 20, 589-592.

Ischukova, L.P., 1997. The Streltsovskoye Uranium District, in: TECDOC-961 (Ed.), Changes and events in uranium deposit development, exploration, resources, production and the world supplydemand relationship. IAEA, Vienna, pp. 237-250.

Jahn, B.M., Litvinovsky, B.A., Zanvilevich, A.N., Reichow, M., 2009. Peralkaline granitoid magmatism in the Mongolian-Transbaikalian Belt: Evolution, petrogenesis and tectonic significance. Lithos 113, 521-539. 
Jerden Jr., J.L., Sinha, A.K., 2003. Phosphate based immobilization of uranium in an oxidizing bedrock aquifer. Applied Geochemistry 18, 823-843.

Kashiwaya, K., Ochiai, S., Sakai, H., Kawai, T., 2001. Orbit-related long-term climate cycles revealed in a 12-Myr continental record from Lake Baikal. Nature 410, 71-74.

Kelly, S.D., 2010. Chapter 14 - Uranium Chemistry in Soils and Sediments, in: Balwant, S., Markus, G. (Eds.), Developments in Soil Science. Elsevier, pp. 411-466.

Khlopkov, A., 2008. The Angarsk project: enrichment vs. proliferation. Security Index: A Russian Journal on International Security 14, 27-44.

Klinkhammer, G.P., Palmer, M.R., 1991. Uranium in the oceans: Where it goes and why. Geochimica et Cosmochimica Acta 55, 1799-1806.

Knauss, K., Ku, T.-L., 1983. The elemental composition and decay-series radionuclide content of plankton from the East Pacific. Chemical Geology 39, 125-145.

Koeppenkastrop, D., De Carlo, E.H., 1992. Sorption of rare-earth elements from seawater onto synthetic mineral particles: An experimental approach. Chemical Geology 95, 251-263.

Ku, T.-L., Knauss, K.G., Mathieu, G.G., 1977. Uranium in open ocean: concentration and isotopic composition. Deep Sea Research 24, 1005-1017.

Lagauzère, S., Motelica-Heino, M., Viollier, E., Stora, G., Bonzom, J.M., 2013. Remobilisation of uranium from contaminated freshwater sediments by bioturbation. Biogeosciences Discussions 10, 17001-17041.

Laverov, N.P., Velichkin, V.I., Fujiwara, A., Shikazono, N., Aleshin, A.P., Asadulin, E.E., Golubev, V.N., Krylova, T.L., Pek, A.A., Chernyshev, I.V., 2009. Uranium Behavior in the Process of Primary Pitchblende Ores Alteration by the Post-ore Hydrothermal Solutions: An Application to Assessment of Uranium Migration from Underground Spent Nuclear Fuel Repositories. Resource Geology 59, 342-358.

Lead, J.R., Wilkinson, K.J., 2006. Aquatic Colloids and Nanoparticles: Current Knowledge and Future Trends. Environmental Chemistry 3, 159-171. 
Lenhart, J.J., Cabaniss, S.E., MacCarthy, P., Honeyman, B.D., 2000. Uranium (VI) complexation with citric, humic and fulvic acids. Radiochimica Acta 88, 345.

Lenhart, J.J., Honeyman, B.D., 1999. Uranium(VI) sorption to hematite in the presence of humic acid. Geochimica et Cosmochimica Acta 63, 2891-2901.

Li, D., Kaplan, D.I., 2012. Sorption coefficients and molecular mechanisms of Pu, U, Np, Am and Tc to Fe (hydr)oxides: A review. Journal of Hazardous Materials 243, 1-18.

Li, Y.-H., Gregory, S., 1974. Diffusion of ions in sea water and in deep-sea sediments. Geochimica et Cosmochimica Acta 38, 703-714.

Li, Y.-H., Sohrin, Y., Takamatsu, T., 2011. Lake Biwa and the ocean: geochemical similarity and difference. Limnology 12, 89-101.

Litvinovsky, B.A., Tsygankov, A.A., Jahn, B.M., Katzir, Y., Be'eri-Shlevin, Y., 2011. Origin and evolution of overlapping calc-alkaline and alkaline magmas: The Late Palaeozoic post-collisional igneous province of Transbaikalia (Russia). Lithos 125, 845-874.

Logatchev, N.A., 2003. History and geodynamics of the Baikal rift. Russian Geology and Geophysics 44, 391-406.

Lomonosov, I., Antipin, V., Lomonosova, T., Gapon, A., 2001. Comparison of composition and geochemical features of bedrocks and solid runoff of big rivers of the Baikal catchment basin (in Russian). Russian Geology and Geophysics 42, 267-287.

Mackay, A.W., Flower, R.J., Kuzmina, A.E., Granina, L.Z., Rose, N.L., Appleby, P.G., Boyle, J.F., Battarbee, R.W., 1998. Diatom succession trends in recent sediments from Lake Baikal and their relation to atmospheric pollution and to climate change. Philosophical Transactions of the Royal Society B: Biological Sciences 353, 1011-1055.

Maerki, M., Müller, B., Wehrli, B., 2006. Microscale mineralization pathways in surface sediments: A chemical sensor study in Lake Baikal. Limnology and Oceanography 51, 1342-1354.

Maerki, M., Wehrli, B., Dinkel, C., Müller, B., 2004. The influence of tortuosity on molecular diffusion in freshwater sediments of high porosity. Geochimica et Cosmochimica Acta 68, 1519-1528. 
Markich, S.J., 2002. Uranium Speciation and Bioavailability in Aquatic Systems: An Overview. TheScientificWorldJOURNAL 2, 707-729.

Martin, P., Boes, X., Goddeeris, B., Fagel, N., 2005. A qualitative assessment of the influence of bioturbation in Lake Baikal sediments. Global and Planetary Change 46, 87-99.

März, C., Poulton, S.W., Brumsack, H.J., Wagner, T., 2012. Climate-controlled variability of iron deposition in the Central Arctic Ocean (southern Mendeleev Ridge) over the last 130,000 years. Chemical Geology 330-331, 116-126.

McManus, J., Berelson, W.M., Klinkhammer, G.P., Hammond, D.E., Holm, C., 2005. Authigenic uranium: Relationship to oxygen penetration depth and organic carbon rain. Geochimica et Cosmochimica Acta 69, 95-108.

Meyers, P.A., Ishiwatari, R., 1993. Lacustrine organic geochemistry-an overview of indicators of organic matter sources and diagenesis in lake sediments. Organic Geochemistry 20, 867-900.

Misaelides, P., Katranas, T., Godelitsas, A., Klewe-Nebenius, H., Anousis, I., 2002. The chemical behavior of the natural microporous manganese-oxide todorokite in actinides (Th, $\mathrm{U}, \mathrm{Pa}$ ) aqueous solutions. Separation Science and Technology 37, 1109-1121.

Moore, M.V., Hampton, S.E., Izmest'Eva, L.R., Silow, E.A., Peshkova, E.V., Pavlov, B.K., 2009. Climate Change and the World's "Sacred Sea" - Lake Baikal, Siberia. BioScience 59, 405-417.

Moore, T.C., Klitgord, K.D., Golmshtok, A.J., Weber, E., 1997. Sedimentation and subsidence patterns in the central and north basins of Lake Baikal from seismic stratigraphy. Geological Society of America Bulletin 109, 746-766.

Morford, J.L., Emerson, S., 1999. The geochemistry of redox sensitive trace metals in sediments. Geochimica et Cosmochimica Acta 63, 1735-1750.

Morford, J.L., Martin, W.R., Carney, C.M., 2009a. Uranium diagenesis in sediments underlying bottom waters with high oxygen content. Geochimica et Cosmochimica Acta 73, 2920-2937. 
Morford, J.L., Martin, W.R., François, R., Carney, C.M., 2009b. A Model for Uranium, Rhenium, and Molybdenum Diagenesis in Marine Sediments Based on Results From Coastal Locations. Geochimica et Cosmochimica Acta 73, 2938--2960.

Morford, J.L., Russell, A.D., Emerson, S., 2001. Trace metal evidence for changes in the redox environment associated with the transition from terrigenous clay to diatomaceous sediment, Saanich Inlet, BC. Marine Geology 174, 355-369.

Morgenstern, U., Ditchburn, R.G., Vologina, E.G., Sturm, M., 2013. ${ }^{32}$ Si dating of sediments from Lake Baikal. Journal of Paleolimnology 50, 345-352.

Morin, G. et al., 2016. Mononuclear U(IV) complexes and ningyoite as major uranium species in lake sediments. Geochemical Perspectives Letter, 2: 95-105.

Müller, B., 1996. ChemEQL V. 2.0. Eidgenössische Anstalt für Wasserversorgung, Dübendorf, Switzerland, p. A program to calculate chemical speciation and chemical equilibria.

Müller, B., Maerki, M., Schmid, M., Vologina, E.G., Wehrli, B., Wüest, A., Sturm, M., 2005. Internal carbon and nutrient cycling in Lake Baikal: sedimentation, upwelling, and early diagenesis. Global and Planetary Change 46, 101-124.

Nagao, S., Yanase, N., Yamamoto, M., Kofuji, H., Sohrin, Y., Amano, H., 2002. The geochemistry of uranium in pore waters from lake sediments. Journal of Radioanalytical and Nuclear Chemistry 252, 225-232.

Nico, P.S., Stewart, B.D., Fendorf, S., 2009. Incorporation of Oxidized Uranium into Fe (Hydr)oxides during Fe(II) Catalyzed Remineralization. Environmental Science \& Technology 43, 7391-7396. Och, L.M., Müller, B., Voegelin, A., Ulrich, A., Göttlicher, J., Steiniger, R., Mangold, S., Vologina, E.G., Sturm, M., 2012. New insights into the formation and burial of Fe/Mn accumulations in Lake Baikal sediments. Chemical Geology 330-331, 244-259.

Och, L.M., Müller, B., Wichser, A., Ulrich, A., Vologina, E.G., Sturm, M., 2014. Rare earth elements in the sediments of Lake Baikal. Chemical Geology 376, 61-75. 
Ohnuki, T., Kozai, N., Samadfam, M., Yasuda, R., Yamamoto, S., Narumi, K., Naramoto, H., Murakami, T., 2004. The formation of autunite $(\mathrm{Ca}(\mathrm{UO} 2) 2(\mathrm{PO} 4) 2 \mathrm{nH} 2 \mathrm{O})$ within the leached layer of dissolving apatite: incorporation mechanism of uranium by apatite. Chemical Geology 211, 114.

Orians, K.J., Merrin, C.L., 2009. Refractory metals, in: Steele, J.H., Thorpe, S.A., Turekian, K.K. (Eds.), Marine Ecological Processes: A derivative of the Encyclopedia of Ocean Sciences, 2nd ed, pp. $52-63$.

Ortiz-Bernad, I., Anderson, R.T., Vrionis, H.A., Lovley, D.R., 2004. Resistance of Solid-Phase U(VI) to Microbial Reduction during In Situ Bioremediation of Uranium-Contaminated Groundwater. Applied and Environmental Microbiology 70, 7558-7560.

Palmer, M.R., Edmond, J.M., 1993. Uranium in river water. Geochimica et Cosmochimica Acta 57, 4947-4955.

Partin, C.A., Bekker, A., Planavsky, N.J., Scott, C.T., Gill, B.C., Li, C., Podkovyrov, V., Maslov, A., Konhauser, K.O., Lalonde, S.V., Love, G.D., Poulton, S.W., Lyons, T.W., 2013. Large-scale fluctuations in Precambrian atmospheric and oceanic oxygen levels from the record of $U$ in shales. Earth and Planetary Science Letters 369-370, 284-293.

Petrov, L.L., Kornakov, Y.N., Persikova, L.A., Anchutina, E.A., 1999. Reference Samples of Lake Baikal Bottom Sediments - An Essential Part of Regional Collection of Reference Samples. International Journal of Environmental Analytical Chemistry 74, 275-288.

Phillips, E.P., Landa, E., Lovley, D., 1995. Remediation of uranium contaminated soils with bicarbonate extraction and microbial U(VI) reduction. Journal of Industrial Microbiology 14, 203-207.

Plank, T., Langmuir, C.H., 1998. The chemical composition of subducting sediment and its consequences for the crust and mantle. Chemical Geology 145, 325-394. 
Pogodaeva, T.V., Zemskaya, T.I., Golobokova, L.P., Khlystov, O.M., Minami, H., Sakagami, H., 2007.

Chemical composition of pore waters of bottom sediments in different Baikal basins. Russian Geology and Geophysics 48, 886-900.

Pokrovsky, O.S., Viers, J., Dupré, B., Chabaux, F., Gaillardet, J., Audry, S., Prokushkin, A.S., Shirokova, L.S., Kirpotin, S.N., Lapitsky, S.A., Shevchenko, V.P., 2012. Biogeochemistry of carbon, major and trace elements in watersheds of northern Eurasia drained to the Arctic Ocean: The change of fluxes, sources and mechanisms under the climate warming prospective. Comptes Rendus Geoscience 344, 663-677.

Poulton, S.W., Canfield, D.E., 2005. Development of a sequential extraction procedure for iron: implications for iron partitioning in continentally derived particulates. Chemical Geology 214, 209-221.

Rai, D., Felmy, A.R., Ryan, J.L., 1990. Uranium(IV) hydrolysis constants and solubility product of $\mathrm{UO}_{2} \bullet \mathrm{xH}_{2} \mathrm{O}(\mathrm{am})$. Inorganic Chemistry 29, 260-264.

Rudnick, R.L., Gao, S., 2004. Composition of the Continental Crust, in: Holland, H.D., Turekian, K.K. (Eds.), Treatise on Geochemistry. Elsevier, Amsterdam, pp. 1-64.

Sani, R.K., Peyton, B.M., Amonette, J.E., Geesey, G.G., 2004. Reduction of uranium(VI) under sulfatereducing conditions in the presence of Fe(III)-(hydr)oxides. Geochimica et Cosmochimica Acta 68, 2639-2648.

Schulz, H.D., 2006. Quantification of Early Diagenesis: Dissolved Constituents in Pore Water and Signals in the Solid Phase, in: Schulz, H.D., Zabel, M. (Eds.), Marine Geochemistry. Springer, Berlin, Heidelberg, pp. 73-124.

Schwarzenbach, R.P., Gschwend, P.M., Imboden, D.M., 1993. Environmental Organic Chemistry. Wiley-Interscience, New York.

Schwertmann, U., Stanjek, H., Becher, H.-H., 2004. Long-term in vitro transformation of 2-line ferrihydrite to goethite/hematite at 4, 10, 15 and $25^{\circ} \mathrm{C}$. Clay Minerals 39, 433-438. 
Sherman, D.M., Peacock, C.L., Hubbard, C.G., 2008. Surface complexation of U(VI) on goethite ( $\alpha$ FeOOH). Geochimica et Cosmochimica Acta 72, 298-310.

Stewart, B.D., Mayes, M.A., Fendorf, S., 2010. Impact of Uranyl-Calcium-Carbonato Complexes on Uranium(VI) Adsorption to Synthetic and Natural Sediments. Environmental Science \& Technology 44, 928-934.

Stookey, L.L., 1970. Ferrozine---a new spectrophotometric reagent for iron. Analytical Chemistry 42, 779-781.

Taylor, S.R., McLennan, S.M., 1995. The geochemical evolution of the continental crust. Reviews of Geophysics 33, 241-265.

Thamdrup, B., Fossing, H., Jørgensen, B.B., 1994. Manganese, iron and sulfur cycling in a coastal marine sediment, Aarhus bay, Denmark. Geochimica et Cosmochimica Acta 58, 5115-5129.

Torres, N.T., Och, L.M., Hauser, P.C., Furrer, G., Brandl, H., Vologina, E., Sturm, M., Burgmann, H., Mueller, B., 2014. Early diagenetic sediment processes generate iron and manganese oxide layers in the sediments of Lake Baikal, Siberia. Environmental Science: Processes \& Impacts $16,879-889$.

Vodyanitskii, Y.N., 2011. Chemical aspects of uranium behavior in soils: A review. Eurasian Soil Sc. 44, 862-873.

Vologina, E.G., Sturm, M., 2009. Types of Holocene deposits and regional pattern of sedimentation in Lake Baikal. Russian Geology and Geophysics 50, 722-727.

Vologina, E.G., Sturm, M., Vorob'eva, S.S., Granina, L.Z., Toshchakov, S.Y., 2003. Character of sedimentation in Lake Baikal in the Holocene. Russian Geology and Geophysics 44, 407-421.

Vologina, E.G., Sturm, M., Vorobyeva, S.S., Granina, L.Z., 2000. New results of high-resolution studies of surface sediments of Lake Baikal. Terra Nostra 9, 115-131.

Votintsev, K.K., Glazunov, I.V., Tolmacheva, A.P., 1965. Hydrochemistry of the rivers of the basin of Lake Baikal. Izdatel'stvo, Nauka. 
Waite, T.D., Davis, J.A., Payne, T.E., Waychunas, G.A., Xu, N., 1994. Uranium(VI) adsorption to ferrihydrite: Application of a surface complexation model. Geochimica et Cosmochimica Acta $58,5465-5478$.

Wang, Z., Lee, S.-W., Catalano, J.G., Lezama-Pacheco, J.S., Bargar, J.R., Tebo, B.M., Giammar, D.E., 2012. Adsorption of Uranium(VI) to Manganese Oxides: X-ray Absorption Spectroscopy and Surface Complexation Modeling. Environmental Science \& Technology 47, 850-858.

Watanabe, T., Nakamura, T., Nara, F.W., Kakegawa, T., Horiuchi, K., Senda, R., Oda, T., Nishimura, M., Matsumoto, G.I., Kawai, T., 2009. High-time resolution AMS 14C data sets for Lake Baikal and Lake Hovsgol sediment cores: Changes in radiocarbon age and sedimentation rates during the transition from the last glacial to the Holocene. Quaternary International 205, 12-20.

Wazne, M., Korfiatis, G.P., Meng, X., 2003. Carbonate Effects on Hexavalent Uranium Adsorption by Iron Oxyhydroxide. Environmental Science \& Technology 37, 3619-3624.

Webb, S.M., Fuller, C.C., Tebo, B.M., Bargar, J.R., 2006. Determination of Uranyl Incorporation into Biogenic Manganese Oxides Using X-ray Absorption Spectroscopy and Scattering. Environmental Science \& Technology 40, 771-777.

Wellman, D.M., Gunderson, K.M., Icenhower, J.P., Forrester, S.W., 2007. Dissolution kinetics of synthetic and natural meta-autunite minerals, $\mathrm{X} 3-\mathrm{n}(\mathrm{n})+[(\mathrm{UO} 2)(\mathrm{PO} 4)] 2 \cdot \mathrm{xH} 2 \mathrm{O}$, under acidic conditions. Geochemistry, Geophysics, Geosystems 8, Q11001.

Williams, K.H., Bargar, J.R., Lloyd, J.R., Lovley, D.R., 2013. Bioremediation of uranium-contaminated groundwater: a systems approach to subsurface biogeochemistry. Current Opinion in Biotechnology 24(3), 489-497.

Windom, H., Smith, R., Niencheski, F., Alexander, C., 2000. Uranium in rivers and estuaries of globally diverse, smaller watersheds. Marine Chemistry 68, 307-321.

Yoshioka, T., Ueda, S., Khodzher, T., Bashenkhaeva, N., Korovyakova, I., Sorokovikova, L., Gorbunova, L., 2002. Distribution of dissolved organic carbon in Lake Baikal and its watershed. Limnology 3, 0159-0168. 
Zakharova, E.A., Pokrovsky, O.S., Dupré, B., Zaslavskaya, M.B., 2005. Chemical weathering of silicate rocks in Aldan Shield and Baikal Uplift: insights from long-term seasonal measurements of solute fluxes in rivers. Chemical Geology 214, 223-248.

Zegeye, A., Bonneville, S., Benning, L.G., Sturm, A., Fowle, D.A., Jones, C., Canfield, D.E., Ruby, C., MacLean, L.C., Nomosatryo, S., Crowe, S.A., Poulton, S.W., 2012. Green rust formation controls nutrient availability in a ferruginous water column. Geology 40, 599-602.

Zheng, Y., Anderson, R.F., van Geen, A., Fleisher, M.Q., 2002a. Preservation of particulate nonlithogenic uranium in marine sediments. Geochimica et Cosmochimica Acta 66, 3085-3092.

Zheng, Y., Anderson, R.F., van Geen, A., Fleisher, M.Q., 2002b. Remobilization of authigenic uranium in marine sediments by bioturbation. Geochimica et Cosmochimica Acta 66, 1759-1772.

Zhmodik, S.M., Verkhovtseva, N.V., Mironov, A.G., Ilić, R., Nemirovskaya, N.A., Khlystov, O.M., Klerkx, J., Zhmodik, A.S., 2003. Mapping of uranium and phosphorus in sediments of Lakes Baikal and Issyk-Kul by neutron-induced autoradiography. Radiation Measurements 36, 567-579.

Zhmodik, S.M., Verkhovtseva, N.V., Soloboeva, E.V., Mironov, A.G., Nemirovskaya, N.A., llić, R., Khlystov, O.M., Titov, A.T., 2005. The study of distribution and forms of uranium occurrences in Lake Baikal sediments by the SSNTD method. Radiation Measurements 40, 532-538.

Zhorov, V., Boguslavskiy, S., Babinets, A.Y., Solov'yeva, L., Kirchanova, A., Kir'yakov, P., 1982. Geochemistry of uranium in the Black Sea. Geochimica et Cosmochimica Acta 19, 191-200. 


\section{Figure 1}

Map of Lake Baikal, Siberia, and its geological setting (modified after a compilation of Parfenov et al., 2003). The yellow circles indicate the coring sites from the field campaign undertaken in 2010 (Och et al., 2012). The terranes are of Archean to Paleozoic age and include various lithologies while the Precambrian/Paleozoic granitoids are the main constituents of the Mongolian-Transbaikalian belt (MTB) which can contain some mafic rocks (Fagel et al., 2007; Jahn et al., 2009; Litvinovsky et al., 2011).

\section{Figure 2}

Geochemical profiles of total $\mathrm{U}, \mathrm{U}_{\mathrm{NL}}$ (according to equation 6), total organic carbon (TOC), total sulphur (TS) and $\mathrm{Fe} / \mathrm{Sc}$ across the sediment cores $\mathrm{A}$ to $\mathrm{D}$ and the respective pore water profiles of $\mathrm{U}, \mathrm{U} / \mathrm{Sc}$, $\mathrm{Fe}$ and $\mathrm{SO}_{4}{ }^{2-}$ (see supplementary information; Och et al., 2012). Note that the $U_{\mathrm{NL}}$ value indicated by the dashed interval at a depth of $15 \mathrm{~cm}$ in core $\mathrm{C}$ is to be considered with caution since its calculation resulted in a value significantly below zero, possibly due to analytical errors. The oxygenated interval on top of the sediment is shaded blue and the Fe- and Mn-oxide layers are in light and dark grey respectively. The dominant redox processes are simplified on the right according to Och et al. (2012).

\section{Figure 3}

Pourbaix diagrams showing the predominant $U$ phases without (a) and with (b) Fe oxide surfaces. For the construction of latter diagram we used $10 \mathrm{~g} \mathrm{l}^{-1}$ adsorbent with a surface area of $10 \mathrm{~g} \mathrm{~m}^{-2}$ and $7 \cdot 10^{-5}$ mol active surface sites $\mathrm{g}^{-1}$ and a ionic strength of $10 \mathrm{mmol} \mathrm{I}^{-1}$. Concentrations of dissolved components were $1 \mathrm{mmol} \mathrm{I}^{-1}$ $\mathrm{Ca}^{2+}, 2 \mathrm{mmol} \mathrm{I}^{-1} \mathrm{HCO}_{3}{ }^{-}$, and $10^{-7} \mathrm{moll}^{-1} \mathrm{UO}_{2}{ }^{2+}$. The shaded intervals represent the $\mathrm{pH}$ range (Maerki et al., 2006) and $\mathrm{pE}$, based on pore water concentrations of $\mathrm{Fe}(\mathrm{II})$ (equation 6), to be expected in Lake Baikal sediments.

\section{Figure 4}

The relative distribution of lithogenic $U\left(U_{L}\right)$ and non-lithogenic $U\left(U_{N L}\right)$ according to equation (6) across the four cores analyzed in the present study. Note that the fraction of $U_{L}$ increases throughout the sediment cores, likely due to its more refractory nature. The fraction of authigenic $U\left(U_{\text {auth }}\right)$ represents $U_{N L}$ formed through early diagenetic processes and is an estimation based on the assumption that $\mathrm{U}_{\mathrm{NL}}$ formed within the water column is gradually being remobilized in the sediment and the pore water $U$ fluxes (see Fig. 2). 


\section{Figure 5}

Iron speciation profiles through cores $\mathrm{A}$ and $\mathrm{C}$ and an interval in core $\mathrm{B}$ as well as the relative fractions of the Fe-oxides and Fe(II) phases are shown. Note that Fe(II) concentrations are given in permil.. The total phosphorus contents in cores $\mathrm{A}$ and $\mathrm{C}$ are shown on the right together with $\mathrm{P} / \mathrm{Fe}$ ratios. The particulate and pore water $U$ concentrations are from figure 2 and shown here for guidance; the scale reaches from 0 to 25 ppm for concentrations in the sediment and from 0 to $15 \mu \mathrm{gl}^{-1}$ in the pore water, respectively.

\section{Figure 6}

The profiles of $U_{\mathrm{NL} \text {-auth }}$ (as estimated from Fig. 4) and TOC within cores $A$ to $D$ and the covariation patterns as well as the trendlines between mass accumulation rates (MARs) of organic carbon ( $\mathrm{C}_{\text {org }}$ ) and average $\mathrm{C} / \mathrm{N}$ ratios. 

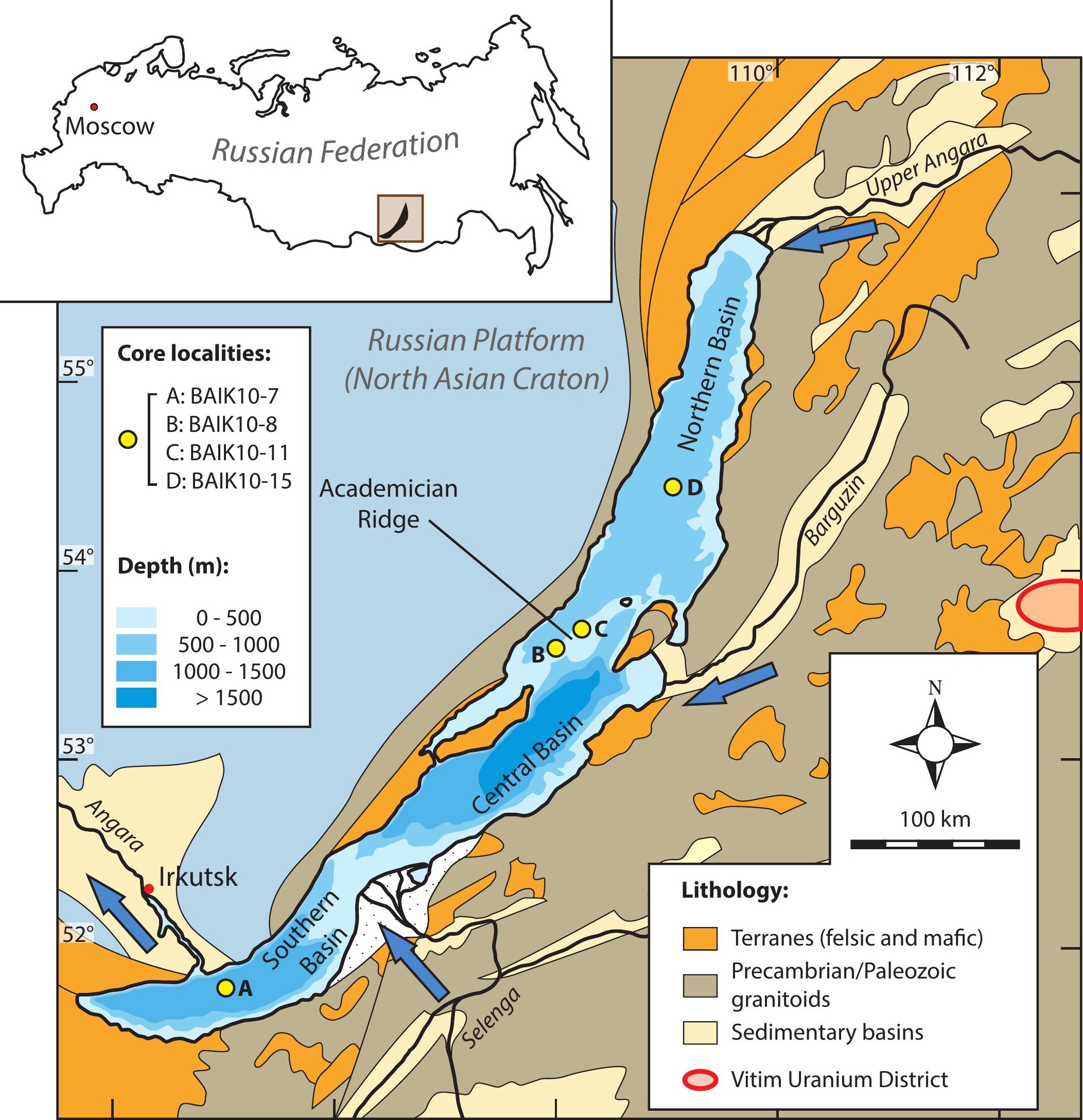


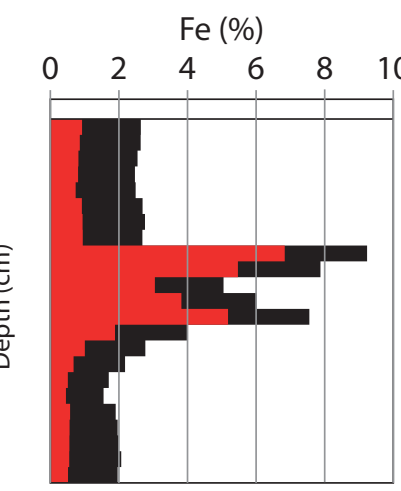

Fe (\%)

Fe (\%o)

$\%$

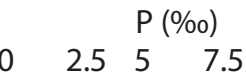
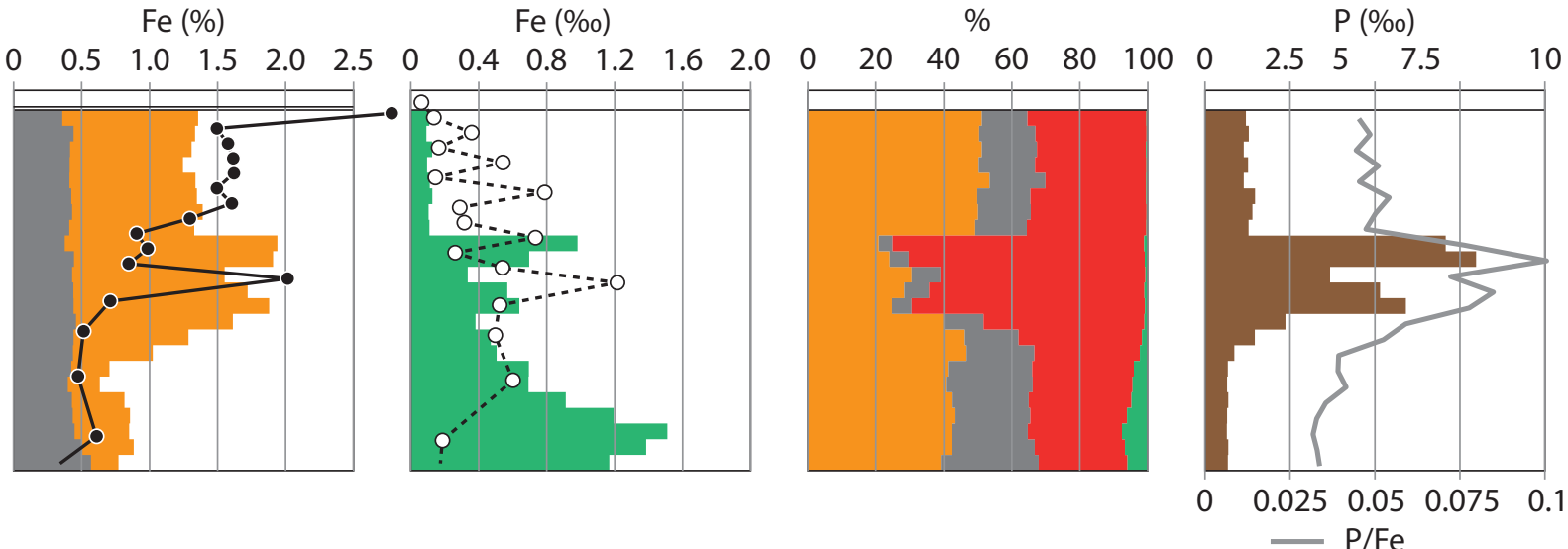

B

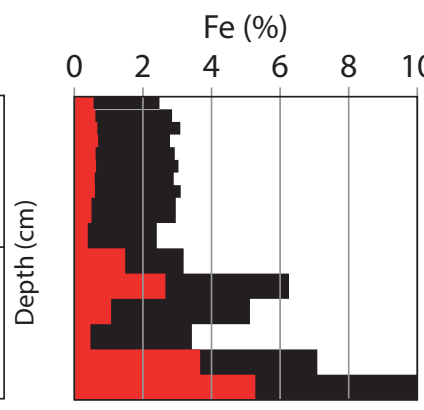

Fe $(\%)$

$\mathrm{Fe}(\%)$

$\%$
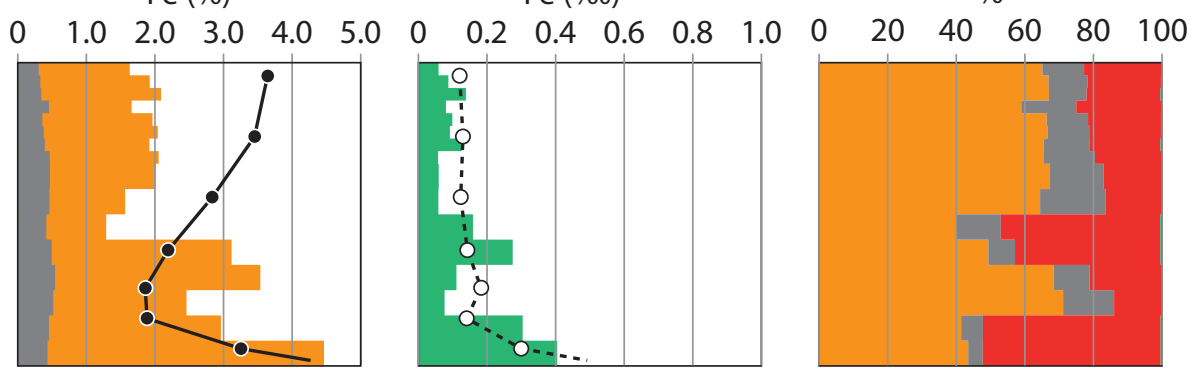

\begin{tabular}{|l}
+ \\
$\sim$ \\
+ \\
$\sim$ \\
+ \\
$\sim$
\end{tabular}

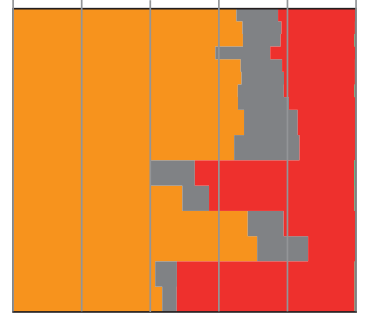

Total extracted $\mathrm{P}$

$\begin{array}{llllll}0 & 2 & 4 & 6 & 8 & 10\end{array}$

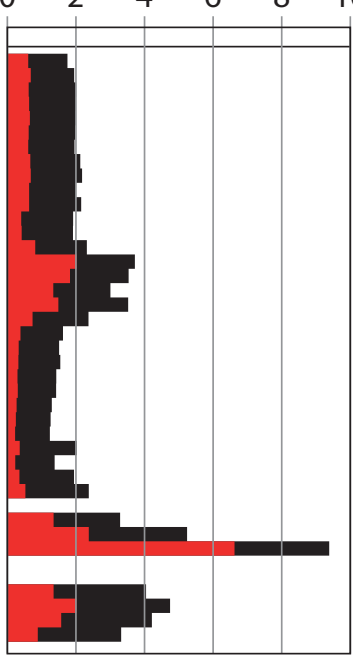

Total extracted Fe

Amorphous/weakly crystalline

Fe-(oxihydr)oxides (e.g. ferrihydrite, lepidocrocite) and products of later Fe(II) oxidation
Fe (\%)

Fe $(\% \circ)$

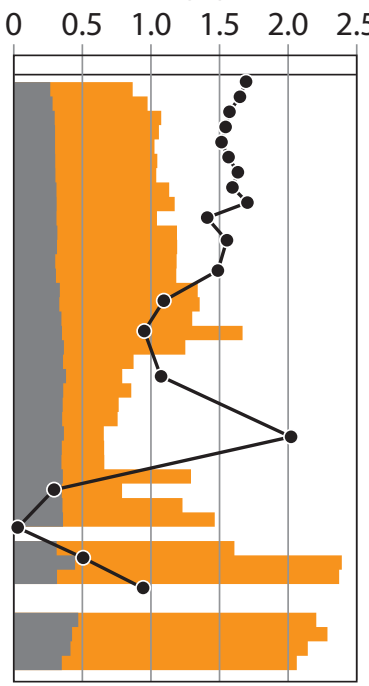

crystalline Fe-oxides (e.g. hematite, goethite) Magnetite
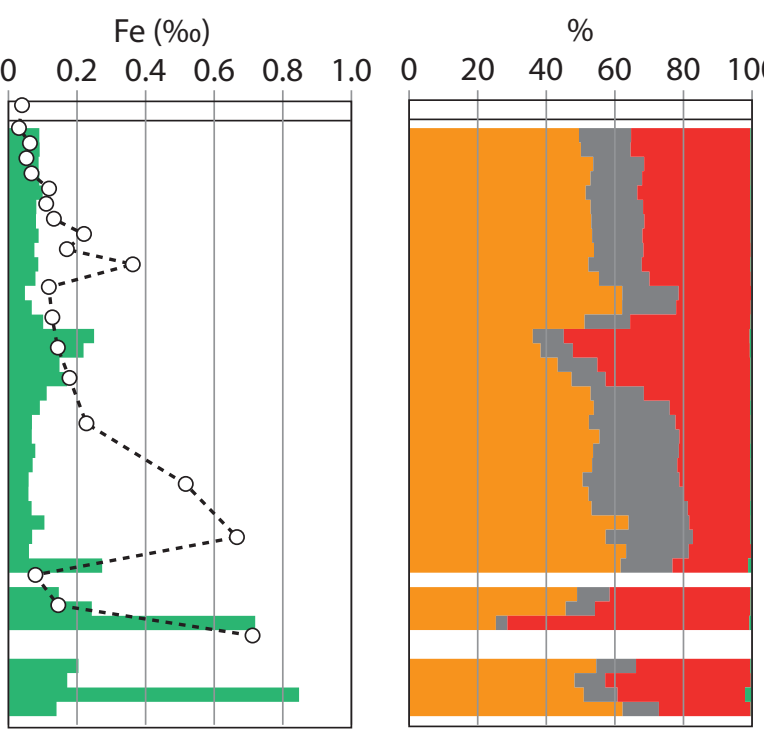

$\mathrm{Fe}(\mathrm{II})$ (e.g. monosulfides, Fe-carbonates, Fe-phosphates)

Uranium profiles (see Fig. 3 for scale):

-๑- $U_{N L}(p p m)$ $-\infty \quad U\left(\mu \mathrm{gl}^{-1}\right)$

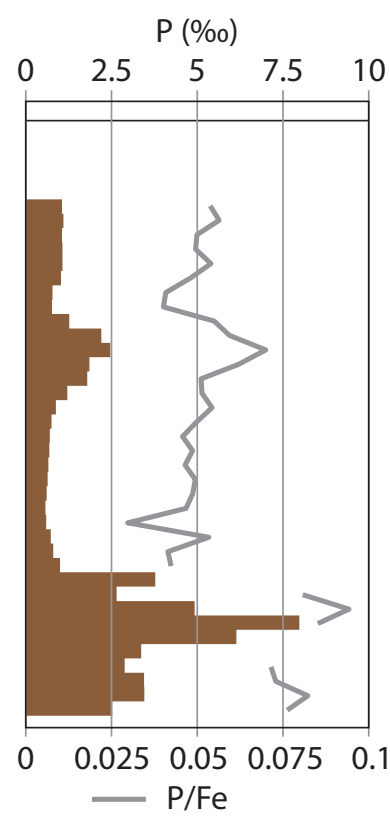


Table 1: Uranium concentrations and fluxes into Lake Baikal via its largest tributaries. References: ${ }^{1}$ Falkner et al., 1997, * surface water concentration from Falkner et al., 1997, ${ }^{2}$ Calculated using data from Bobrov et al., 2001.

\begin{tabular}{|c|c|c|c|c|c|c|}
\hline \multirow[b]{2}{*}{ Rivers } & \multicolumn{3}{|l|}{ Dissolved": $^{1}$} & \multicolumn{3}{|l|}{ Particulate $^{2}:$} \\
\hline & $\begin{array}{l}\text { Flow } \\
\left(10^{12} \mathrm{~kg} \mathrm{a}^{-1}\right)\end{array}$ & $\begin{array}{l}U \\
\left(\mu g^{-1}\right)\end{array}$ & 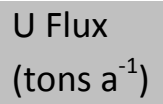 & $\begin{array}{l}\text { Particle input } \\
\left(10^{9} \mathrm{~kg} \mathrm{a}^{-1}\right)\end{array}$ & $\begin{array}{l}\text { U } \\
\text { (ppm) }\end{array}$ & 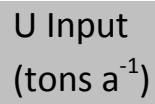 \\
\hline \multicolumn{7}{|l|}{ Inflow: } \\
\hline Selenga & 29.1 & 1.58 & 46 & 2.84 & 6.4 & 18.15 \\
\hline Barguzin & 3.9 & 0.54 & 2.1 & 0.23 & 3.2 & 0.73 \\
\hline Upper Angara & 8.3 & 0.17 & 1.4 & & & \\
\hline \multicolumn{7}{|l|}{ Outflow: } \\
\hline Angara & 58.3 & $0.47^{*}$ & $27.8^{*}$ & & & \\
\hline
\end{tabular}

